\title{
Vulnerability as a heuristic concept for interdisciplinary research: assessing the thematic and methodological structure of empirical life course studies
}

\author{
Doris Hanappi* National Centre of Competence in Research LIVES, University of Lausanne \\ University of California Berkeley, Department of Demography \\ Laura Bernardi $\}$ Institute of Social Sciences and National Centre of Competence in Research LIVES, \\ Dario Spini $\}$ University of Lausanne \\ dorish@demog.berkeley.edu
}

(Received April 2014 Revised December 2014)

\section{Abstract}

Changes in human lives are studied in psychology, sociology, and adjacent fields as outcomes of developmental processes, institutional regulations and policies, culturally and normatively structured life courses, or empirical accounts. However, such studies have used a wide range of complementary, but often divergent, concepts. This review has two aims. First, we report on the structure that has emerged from scientific life course research by focusing on abstracts from longitudinal and life course studies beginning with the year 2000. Second, we provide a sense of the disciplinary diversity of the field and assess the value of the concept of 'vulnerability' as a heuristic tool for studying human lives. Applying correspondence analysis to 10,632 scientific abstracts, we find a disciplinary divide between psychology and sociology, and observe indications of both similarities of-and differences between-studies, driven at least partly by the data and methods employed. We also find that vulnerability takes a central position in this scientific field, which leads us to suggest several reasons to see value in pursuing theory development for longitudinal and life course studies in this direction.

\section{Introduction}

The study of human lives has become one of the most progressive areas of social science research over the past quarter-century, spreading across the social and behavioural sciences. With this change has come an acknowledgement that human personality and social pathways in transforming societies develop over a long stretch of time (Elder, 1994; Mayer, 2009). From this 'long way of thinking' (Elder, 1994, p. 4) has emerged a longitudinal and life course perspective that is tied to major progress in longitudinal data collection (Mayer, 2009). Longitudinal and life course analysis today has extended across disciplinary boundaries and specialty areas within particular disciplines (in developmental psychology see, e.g., Bronfen- brenner, 1979; in social history see, e.g., Elder, 1994; and in gerontology see, e.g., Streib \& Binstock, 1990). We sympathise with the idea that the study of the life course is a progressive field with some degree of intellectual unity (Butz \& Torrey, 2006), but too often it is still pursued within fragmented disciplines.

Now entering its stage of maturity, Mayer (2009) concluded in his seminal work that progress in longitudinal data collection and methods has driven disciplines toward greater methodological convergence in their studies of social phenomena across the life course. Moreover, longitudinal methods motivated the study of the life course from distinct or even disparate intellectual territories. However, the newly existing data 
sources, new methods, and potential new theory development call for a more profound assessment of larger populations over a longer stretch of time, and a systematic examination of the whole life course within and across different domains and within and across institutional contexts.

Our article has two research aims. Research Aim 1 is to empirically assess whether life course studies share thematic and methodological common ground, in terms of topics covered, life stages studied, and methods used. The Research Aim 2 is to assess the current use of the concept of vulnerability in life course studies. By now, there is consensus among life course scholars that theory development beyond orienting concepts has not yet lived up to its full potential (e.g., Elder, 1985; Mortimer \& Shanahan, 2003; George, 2003; O'Rand, 2006; Heinz \& Marshall, 2005; Settersten, 2003), and that the lack of interdisciplinary concepts is all the more important to scientific progress as more new data sources and longitudinal methods are available (Mayer, 2009). Giving credit to these arguments, we assess whether the concept of vulnerability can be a viable heuristic for interdisciplinary life course research: We assess how frequently this concept is used and, more importantly, we position it into the field structure that we have explored in the first research aim, to assess whether it is used equally in terms of making reference to the same concept in the different disciplines.

We understand vulnerability as a lack of resources or as a social weakness (Ranci, 2010). Spini, Hanappi, Bernardi, Oris, \& Bickel_(2013) suggested that, for individuals or groups that are in a zone in which functionality is only secured at the limits of available resources, vulnerability may be manifested if the individual or group is challenged by critical events or depleted by chronic stresses or environmental pressures. Until the limits of available resources have no observable adverse consequences, vulnerability often remains latent. Other concepts, such as insecurity, relate to welldefined insecurities; for instance, job insecurity relates to job instability and employment precariousness (Elman \& O'Rand, 2002). There is general agreement that this concept mainly refers to the perception that one's current job might be lost (Esser \& Olsen, 2011) and such perception increases feelings of powerlessness and a lack of control (Greenhalg \& Rosenblatt, 1984). The concept of risks has received considerable attention in the last decade in the social sciences after the publication of the book entitled Risk Society by Beck (1992). Risks are indeed associated with vulnerability, but the terms are not synonyms. Following Sirven (2007), risks are expressed by the probability that an event occurs whose consequences are generally known (for a main definition of risk see, e.g., Knight, 1921). He describes risks as the conjunction of a particular event that might possibly occur and people's vulnerability to experience such an event. Following this perspective, we can describe vulnerability in terms of what can happen to a population, given that certain events occur (i.e., events shape vulnerability), whereby the occurrence of such events is influenced by people's vulnerability itself (vulnerability shapes the probability of an event or hazard, as Sirven states).

Moreover, this concept is inextricably linked with human development at the intersection of the biological, psychological, and social domains (Baltes, Lindenberger, \& Staudinger, 1998; Armingeon \& Bonoli, 2006; Bronfenbrenner, 1989; Heinz \& Marshall, 2005; Kohli, 2007). We restrict ourselves to dimensions of 'vulnerability' that pertain more broadly to social science in contrast to the biological or corporeal aspects of human development. We further exclude the medical and epidemiological studies for the same reason. ${ }^{1}$

Previous applications of the concept of vulnerability can be found in various fields. However, studies have used a range of sometimes complementary, sometimes divergent concepts to express the various aspects of 'vulnerability' (e.g., Pearlin, 1989; Bronfenbrenner, 1989; Lyonette, Crompton, \& Wall, 2007; McNamara, PittCatsouphes, Matz-Costa, Brown, \& Valcour, 2007; Scherer, 2009). In the study of 'new social risks', scholars have repeatedly associated vulnerability with family discontinuity and labour market uncertainty (e.g., Armingeon \& Bonoli, 2006; Esping-Andersen, 1990; O'Rand, 2003; Hanappi, 2011; Western, Bloome, Sosnaud, \& Tach, 2012). Related studies can be divided into two fields: One that emphasises the fact that individualisation trends cause new responsibilities, hardships, and stress in the life course (Kohli, 2007; Ehrenberg, 1995; Martucelli, 2006). The second field proposes that individualisation tends to be overstated because, according to empirical research, individual 
risks have not replaced the risks that were experienced by entire social classes. In Ireland, Whelan and Maitre (2013) find significant interactions between social class and the life-cycle generating poverty and risk patterns of economic vulnerability - a result that is largely confirmed by a cross-sectional analysis of Ireland, the United Kingdom, Denmark, Finland, Austria, Belgium, France, Germany, and the Netherlands (Pintelon, Cantillon, Bosch, \& Whelan, 2013). Likewise, in a study using event history analysis of the European Community Household Panel, Vandecasteele (2011) found structural and biographical explanations of poverty to be complementary and pointed to major poverty-triggering events such as childbirth or job loss. In the welfare state literature, the concept of vulnerability has been used to point to state insufficiencies in providing adequate solutions to social problems (Esping-Andersen, 2002; Safarti \& Bonoli, 2002; Esping-Andersen, 2009). In sum, concepts that account for the vulnerabilities of groups and individuals are at the intersection of domains such as work and family in a dynamic way-across human lives. That is why we consider such concepts to be particularly promising for advancing life course research.

We empirically assess the thematic and methodological structure of life course studies by the use of correspondence analyses and provide an overview of topics and life stages covered and methods used in this field of research. Unlike classic literature reviews, empirical literature assessments based on correspondence analysis do not require prior interpretative techniques. This makes them a very flexible and efficient tool for assessing the semantic structure of any research domain. We also identify the locations of research on vulnerability in/across various disciplines, thus expanding upon noteworthy literature reviews that focus on one specific research area (e.g., Walsh, 1996; Paugam, 2000). We give preference to scientific material published since the year 2000, to empirical research applying longitudinal designs to study changes in human lives over a longer stretch of time or over the duration of a lifetime, or to those that focus on particular episodes (such as the transition to employment) or narrow life phases; we also include cohort studies (rather than cross-sectional designs), studies on changes of lives within or across life domains, and studies that treat life course development as an outcome of personal characteristics and institutional or structural conditions. Finally, we add studies that locate human lives in community contexts, kinship structures, or families.

This paper is organised in three sections. In the next section, we explain how we obtained our data and describe the method that we used. In the subsequent section, we provide a shorthand overview indicating how sociologists, developmental psychologists, demographers, social historians, and gerontologists have applied a life course perspective to understand changes in human lives. For this purpose, we illustrate the location of the themes covered, methods, and data in the respective semantic field space. In the remainder, we provide a first attempt, on the basis of that evidence, to address Research Aim 1, regarding thematic and methodological common ground in empirical life course studies, and Research Aim 2, which investigates the value of 'vulnerability' as a heuristic concept that can contribute to further progress in life course studies.

\section{Method and data}

\subsection{Correspondence analysis}

We use correspondence analysis, which is a multivariate technique commonly employed in sociology (Bourdieu, 1977) and used for exploring textual data (Lebart \& Mirkin, 1993, Lebart, Salem, \& Berry, 2010; Benzecri, 1992; for applications see, e.g., Mussino \& Bernardi, 2010; Spini, Elcheroth, \& Figini, 2008; Salamin \& Hanappi, 2014). It is a descriptive/exploratory technique to analyse simple two-way and multi-way tables containing some measure of correspondence between the rows and columns. The results provide information that is similar to factor analysis techniques, and they allow for the exploration of the structure of categorical variables. It is a technique for describing contingency tables (or cross-tabulations) and certain binary tables (also known as presenceabsence tables) (Lebart \& Mirkin, 1993; Greenacre, 2010).

We apply this technique to explore the thematic and methodological structure of empirical life course studies. In our analysis of scientific article abstracts, we construct a cross-table of frequencies by using the aforementioned disciplines in columns, and themes or methods in rows. Each crosstabulation of frequencies is first standardised so that frequencies across all cells sum to 1.0. 
Subsequently, our goal is to represent the entries in the table of relative frequencies in terms of distances between individual rows and columns. The use of this technique allows for exploration of the simultaneous contribution of themes, methods, and disciplines in the structuring of the research field. The topography of the field emergent from the year 2000 and after shows each theme or method positioned with respect to all of the others (Greenacre, 2010).

\subsection{Data}

Our data covers journal article abstracts from longitudinal and life course research in the social sciences from several categories: first, studies with samples composed of vulnerable populations only (for migration see, e.g., Korinek, Entwisle, \& Jampaklay 2005; for depression see, e.g., Brockman, 2010; Kort-Butler, 2009; for elderly populations see, e.g., Brockmann, 2010; Ha, Carr, Utz, \& Nesse, 2006; for precarious populations see, e.g., Gangl, 2002; Brady, 2006); second, studies that compare vulnerable populations with the 'average' population (e.g., Klimstra, Luyckx, Hale, Goossens, \& Meeus, 2010; Agree, Meoni, \& Klag, 2010); and, third, studies that identify resources, factors, and processes that cause or result from vulnerability (e.g., Hofferth \& Goldcheider, 2010; Hank, 2005; Dunbar et al., 2006). In addition, some contributions include only specific sets of actors in their samples (e.g., adolescents, families, women, and workers), but focus on issues related to vulnerability (e.g., social exclusion, unemployment, and divorce) and, thus, have been included in our data (e.g., Brady, 2006; Friedman, Steinwachs, Temkin-Greener, \& Mukamel, 2006; Drenteea, Clay, Roth, \& Mittelman, 2006). Consistent with the life course perspective (e.g., Mayer, 2009), only articles adopting a longitudinal/dynamic approach have been included, that focus on situations and processes of vulnerable populations or of populations rendering them resilient or vulnerable. ${ }^{2}$ Studies that mention cross-sectional designs have been excluded from this literature search.

Articles from academic and specialised journals have been considered and retrieved from two main bibliographic databases: (1) the PsychINFO database, which is an abstracting and indexing database with more than 3 million records devoted to peer-reviewed literature in the behavioural sciences and mental health; and (2) the FRANCIS database, a 2.6 million-record, bibliographic database covering humanities and social-science topics from an international perspective. The FRANCIS database covers also articles from the disciplinary database Sociological Abstracts, and other related areas such as education, employment, and training. The main search keys have been agreed upon by all authors in consultation with two additional experts in the field (i.e., sociology and social policy, gerontology, demography, psychology, and economics). The list of search keywords applied in our article is summarised in Table 1. The first column includes relevant themes related to vulnerability (Terms 1 ), while the second column lists methods or typical methodological terms indicating longitudinal designs (Terms 2). 
Table 1. Summary of key search terms as they were searched in the databases

\begin{tabular}{|c|c|}
\hline Terms 1 (themes) & Terms 2 (methods) \\
\hline $\begin{array}{l}\text { e.g. depression, satisfaction, victimisation, discrimination, } \\
\text { burnout, violence, illness, disease, deaths, elderly, stigma, } \\
\text { nursing, negative affect, psychic disorder, cumulative } \\
\text { disadvantage, life sequence, work, poverty, precariety, } \\
\text { precarious, employability, employment, employment, job, } \\
\text { mobility, socialbility, social change, profession, career, wage, } \\
\text { earning, labor, occupation, education, school, training, income, } \\
\text { social class, wealth, justice, uncertainty, informal economy, } \\
\text { migration, retirement, pension, turnover, layoff, informal } \\
\text { sector, formal sector, shadow economy, institution, family, } \\
\text { fertility, divorce, kinship, gender, marriage, conjugal, } \\
\text { motherhood, father, parent, spouse, couple, partner, childcare, } \\
\text { childbearing, childbirth, childless, widow, social participation, } \\
\text { social network, social tie, paternity leave, maternity leave, } \\
\text { domestic responsibility, domestic task, household } \\
\text { responsibilities, sibling, reconciliation, work-life balance, union } \\
\text { formation, cognitive process, learning, memory, attention, } \\
\text { motivation, emotion, consciousness, cognitive development, } \\
\text { gerontology, interpersonal process, group process, social } \\
\text { perception, social representation, social cognition, } \\
\text { psychological disorder, anxiety disorder, job performance, } \\
\text { personnel selection, skill, race, intergenerational, daily living } \\
\text { condition, social environment, hospitalisation, morality, ability, } \\
\text { recreation, welfare, peer groups, longevity, deviant bevavior, } \\
\text { equal opportunity, minority, community involvement, isolation, } \\
\text { desaffiliation, vulnerability, aging, personality, coping ... }\end{array}$ & $\begin{array}{l}\text { optimal matching, sequence } \\
\text { analysis, sequence comparison, } \\
\text { sequential pattern, sequencing, } \\
\text { sequence model, time series, } \\
\text { Marcovian, Marcov chain, } \\
\text { Markov chain, Marcov model, } \\
\text { Marcov model, event history, } \\
\text { history, latent growth, latent } \\
\text { curve, growth curve, life story, } \\
\text { life calendar, diary, biographical, } \\
\text { narrative, sequence mining, } \\
\text { structural equation, hazard } \\
\text { model, survival model, survival } \\
\text { analysis, survival data, survival } \\
\text { tree, cox model, longitudinal, } \\
\text { prospective, retrospective, panel, } \\
\text { transition, lifecourse, lifecycle, } \\
\text { lifepaths, lifepatterns, lifeskills, } \\
\text { lifespan, lifestage, lifestory, } \\
\text { lifestress, lifestyle, trajectory, } \\
\text { critical episodes, critical incident, } \\
\text { critical incident, critical life event, } \\
\text { critical life events, critical } \\
\text { movements, critical point, critical } \\
\text { state (not "cross-sectional") ... }\end{array}$ \\
\hline
\end{tabular}

Note. The search syntax was generated in the PSYCHINFO database and adapted for the FRANCIS database. Double extractions of identical articles found in both databases were excluded from the data. English and American spellings were accounted for. Words were truncated in a semi-automatized procedure provided by the SPAD Program to allow for word variation from the root term.

In order to reach the maximum coverage of relevant contributions, the search and extraction of articles has gone far beyond the mere one-step keyword search. The articles retrieved in the initial keyword search have been screened to identify other potentially relevant contributions for this paper and to cover the maximum possible range of methods used to study vulnerability. The initial keyword search in the two databases has resulted in a set of 20,000 articles published in 2,233 journals from all social science fields. Contributions such as literature reviews or other meta-theoretical articles, meta-analyses, short notes, and comments have been excluded. In order to limit the analysed material, we have focused on those journals that published $50 \%$ of all articles corresponding to our search criteria. This led to a cut at 26 articles published at minimum per journal in the observation period so that data from 10,632 articles entered our textual analysis, performed with the SPAD software (Coheris, 2007; see http://www.coheris.com/produits/analytics/logiciel -data-mining/). The software generated a comprehensive vocabulary and repeated segments of words, on the basis of which, subsequent correspondence analyses were performed (Appendix A lists all journals and the number of articles published in these journals) (Morineau \& Aluja-Banet, 1998). Moreover, each article was coded according to its discipline category. The main categories of the discipline variable represent sociology, psychology, demography, gerontology 
and ageing, general social science (which includes specific applied studies and other multi-disciplinary journals, such as gender studies), and specialised youth studies. Indeed, the discipline variable was chosen as the main criteria to plot against the original content from the abstracts, because it appeared to be the most useful in identifying emerging disciplinary divides and directions for future research (in contrast to the year variable, which was less informative). In the next section, we present two applications of correspondence analysis: the first one shows how topics which are covered in empirical life course studies and disciplines structure the research field; the second application shows the correspondence between the used methods and the main disciplines. In both models, key terms related to the concept of vulnerability and life stages have been positioned $a$ posteriori in the field space. We then interpret and discuss the results of the correspondence analysis and point to promising future directions for research.

\section{Results, interpretation, and discussion}

We explore key research themes of longitudinal and life course studies and show how they are associated with different disciplines and where the concept of 'vulnerability' is located within the research field. The salient themes constitute the active row variables; the disciplines presented in Appendix B form the columns of a contingency table. We opted for running the analysis with most frequent repeated segments (e.g., personality disorder) in our extracted abstracts to better capture the meaning of the compound words rather than isolated single words (see also, e.g., Lebart \& Mirkin, 1993; Lebart et al., 2010).

In total, 71 salient themes (i.e., repeated segments) were considered for Model 1 (Appendix B). More specifically, our analysis examines the number of times each discipline (column) coincides with particular themes (which corresponds to the value 1 for the nominal variable). It should be emphasised here that correspondence analysis, like similar methods such as principal component analysis and multi-dimensional scaling, neither generates nor requires any notion of causality between variables, instead allowing us to represent the extent to which different discipline categories "correspond" to different salient themes and the frequency of appearance of these themes in scientific abstracts. To allow for the interpretation of the detailed results, Figure 1 provides a graphical representation of the first two axes and the location of discipline categories and selected research themes in this two-dimensional space. Moreover, selected key terms (words) have been positioned $a$ posteriori into the graph, depending on their potential to ease the reading of the graph; for instance, the terms childhood, adolescence, adulthood, and the elderly are indicative of the age spectrum and life course stage of the examined populations. Their computation is executed separately for each one and they do not actively construct the axes (see the boxed elements in Figure 1). Lebart (1992, p. 60) defines those variables that have only an illustrative purpose as supplementary elements.

In this first analysis, the percentages of variance of the eigenvalues were $67.5 \%$ and $15.0 \%$, respectively, for the first two axes. Factor three carried only $9.1 \%$ of variance, followed by two additional axes with negligible inertias of $4.7 \%$ for the fourth, and $3.7 \%$ for the fifth. These results suggest a two-factor solution in which $82.5 \%$ of the overall variance of our model is explained. The overall structure of the graphical representation suggests an interpretation of the organization of the field along two main dimensions (i.e., the axes in Figure 1). We find that longitudinal and life course studies are well expressed on the first axis on a continuum from a more psychological pole to more sociological, demographic, and general social science research, ${ }^{3}$ and youth studies. Here psychology loads positively, while all other disciplines load negatively, and gerontology and youth studies take a middle position by adopting either an interdisciplinary or disciplinary approach. It is within this distinction that the difference between themes further accentuates this disciplinary divide.

The second axis established the distinction between childhood and old age-in particular, it showed a clear succession along the axis of the different life stages, from childhood to adolescence, midlife and old age (represented here by the single term elderly $)^{4}$. Once isolating the examined age groups of older and younger people, which are highly correlated with gerontology and youth studies, the second axis ranges from the disproportionately fast-growing epidemiological 
studies that capture individual processes related to macro-structural outcomes (e.g., on mental health, health services, and social support) to individuallevel research in which the standard disciplines psychology and social sciences dominate. Most interestingly, none of the salient themes (active variables) indicating the life stage of adulthood entered the most frequent words, while the opposite was true for younger and older age groups. Thus, we can assume that many abstracts deal with the life stage of adolescence, including children, or the elderly, but omit adulthood as an important stage in the life course. We briefly describe and discuss these key dimensions of longitudinal and life course research within disciplines below.

Figure 1. Simultaneous representation in correspondence analysis of disciplines (active column variables) and themes (active row variables)

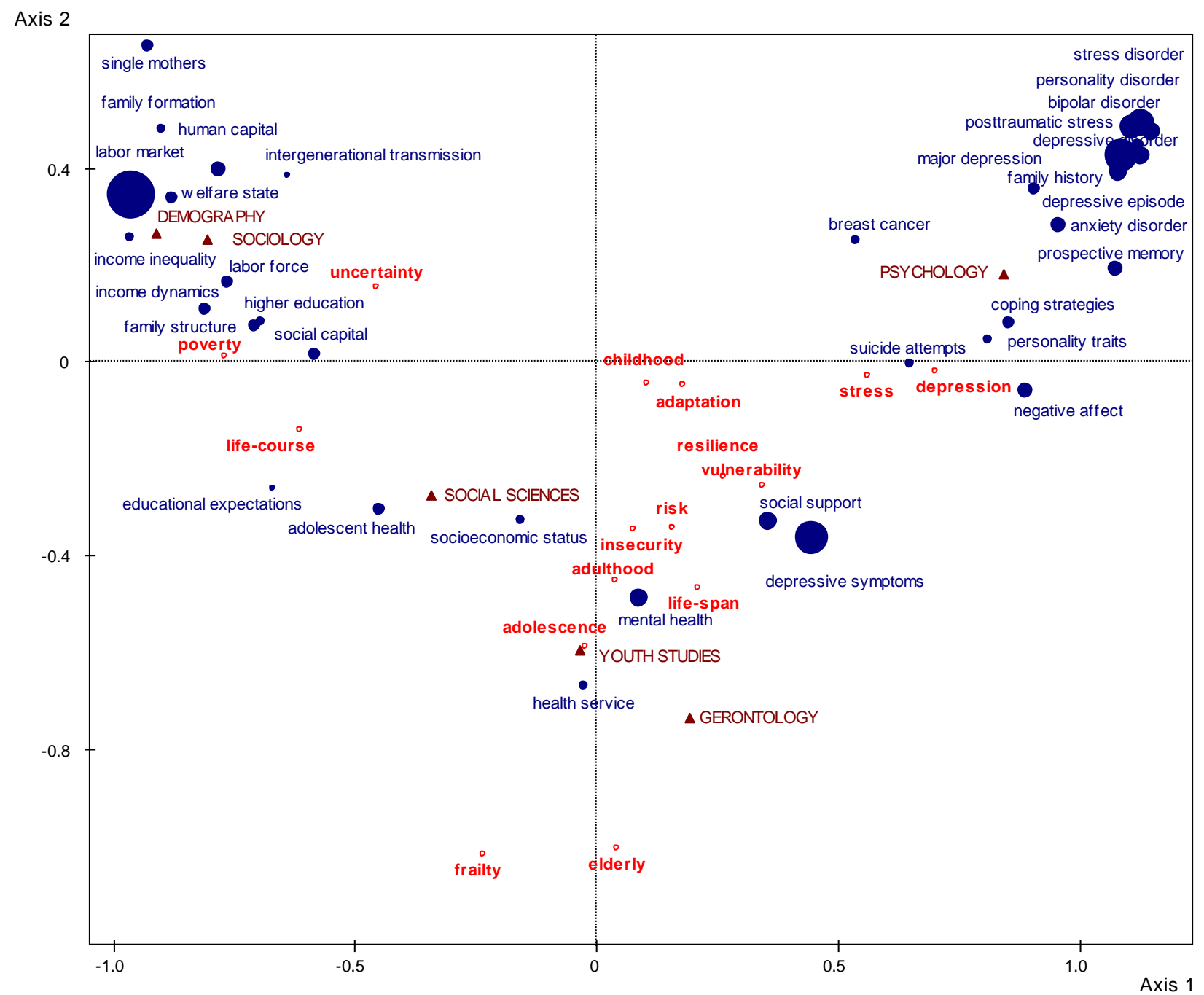

\section{Themes in psychology}

In psychology, research focused, to a large extent, on vulnerable individuals suffering from bipolar disorder, depressive episodes, posttraumatic stress, or personality disorder ${ }^{5}$. Within the discipline we can further distinguish clinical studies and social psychological studies that are closely related to life-span psychology. One can also note that the life-span psychology is closely associated with older ages, as could be expected from its historical origins.

\section{Themes in sociology and demography}

General themes in sociology and demography focused on family formation, education (human capital), the labour market, and the welfare state. 
The position of life course research in the vector space showed its proximity to its American roots and its disciplinary openness for social science disciplines, such as sociology and demography, and applied research, primarily labour market and youth studies (including research on childhood).

\section{Themes in gerontology}

We found that gerontological abstracts strongly determined the second axis, as expressed by a naturally clear dedication to studying people in old age. Thus, abstracts in gerontology often studied frailty in old age and health services rather than all other life stages.

In Model 2 we explore, using the same data set, how common forms of data (active row variables) are associated with disciplines (active column variables), where the frequencies for the number of times each discipline coincides with particular forms of data (Figure 2; Appendix C). In total, 17 salient forms of data or methods entered our second model. For example, the input data would list the number of times one discipline would be related to a specific form of data, such as experimental data or panel data, and would also contain the same information for all other disciplines. For the column variables, 'psychology' determines almost $70 \%$ of the first axis, and only $0.3 \%$ of the second axis; for sociology, the corresponding values would be $15.4 \%$ and $6.0 \%$. The second axis represents social sciences $(35.9 \%)$, youth studies $(27.0 \%)$, and gerontology (18.5\%). For the row variables, we observe that data forms such as experimental data (indicated by the repeated segment 'control group') determine $20.8 \%$ of the first axis and only $4.3 \%$ of the second, while longitudinal data, life stories, and qualitative data mainly contribute to the second axis (the corresponding contributions are $32.1 \%$, $17.5 \%$, and $6.7 \%$ ).

This second analysis also results in a two-factor solution: the first factor explains $65.1 \%$ of the model variance, followed by $17.9 \%$ for the second (see also Appendix C). The other three axes carry altogether less than $20 \%$ of the total variance; thus, they are dropped from the analyses and graphical representation. The overall structure of the graphical representation suggests an interpretation of the field structure along two main dimensions (i.e., axes in Figure 2). We find that the first axis spreads along a continuum that ranges from the analysis of small samples, corresponding, for instance, to experimental designs on the one end to the analyses of larger samples using panel data and event history data on the other. We observe that the disciplines of psychology and sociology explain most of the variance of the first axis, while social sciences, gerontology, and youth studies make up for most of the variance of the second axis. We recall that, in Model 1, the first axis represented the disciplinary divide. Model 2 supports the findings from Model 1 by showing that this disciplinary distinction between psychology and sociology is, to some extent, driven by the data and methods used. For example, experimental data mainly used in psychology loads negatively (in the coordinates section, column 1), while panel data and all other structural forms of data load positively. In addition, we account for the different terminology used for the same analysis techniques in various disciplines. For instance, survival analyses techniques are specifically designed to estimate risks (in the lowerleft quadrant, Figure 2) and are used as a synonym for event history models that are more common in sociology (in the lower-right quadrant, Figure 2). The second axis, which explains considerably less of the model variance $(17.9 \%)$, aligns research areas with the use of particular data that are used to analyse relevant phenomena in the respective fields.

\section{Oppositions among disciplines}

Figure 2 illustrates that there is a core of data that forms the characteristics of the disciplines. Not all methods or data, however, are equally important in pointing out the differences by discipline. Significantly, experimental data, prospective studies, and retrospective data determine the first axis to almost $50 \%$ with a combined absolute contribution of $49.4 \%$. These are opposed to the set of structural and panel data ${ }^{6}$ that also load higher on the first than on the second axis. From gerontological and life-span abstracts, we see that these make use of qualitative data (e.g., life stories, in-depth interviews, and focus groups) and, to a lesser extent, use national longitudinal data sets. 
Figure 2. Simultaneous representation of correspondence analysis of disciplines (active column variables) and data forms (active row variables)

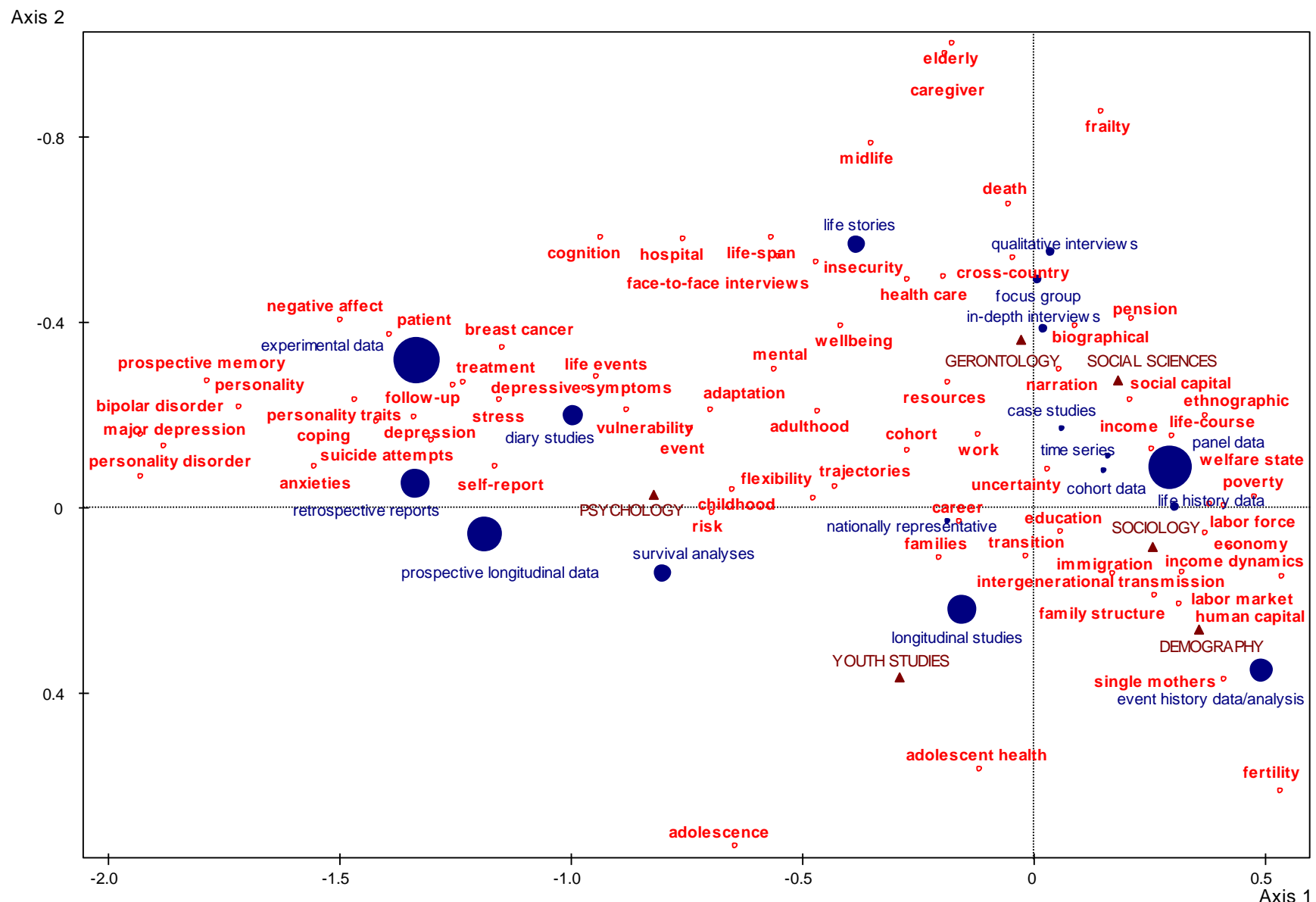

\section{Data used across disciplines}

Longitudinal data, life history, nationally representative surveys, time series, and cohort studies in particular are more likely to be equally employed across disciplines, though their relative weight varies substantially (with the cohort data label being far more employed than the life history label). However, both models show that each discipline may be more focused on specific social phenomena and mechanisms (micro vs. macro). Model 2 also shows that only the second and less important axis differentiates very specific data formats. There is a concentration of individual-level data in the upper part of the graph, where we find diary studies and experimental data (mainly used in disciplinary sub-fields, such as life-span psychology), but also micro qualitative data such as life stories, focus groups, in-depth interviews, and case study designs (mostly in gerontology and social sciences). Towards the centre of the graph, at the crossroad of the axes, we find, instead, the data formats that are most commonly used by all disciplines, such as cohort and life history data and longitudinal data from nationally representative surveys. The proximity of terms such as retrospective and prospective datasets to psychology and of event history and survival analysis to demography, respectively, seem to reflect labelling habits for similar data formats. All in all, the field provides evidence that longitudinal data especially facilitates the use of common methods of causal modelling.

Finally, to aid interpretation, we highlighted some key concepts being illustrative variables and thus having a contribution of 0 for the construction of the vector space of model 2 . This enabled us to locate the key concepts between the prior identified spectrum of disciplines. The psychology pole is characterized by four main concepts: personality, disorder, depression, and coping. This result corroborates another analysis of social psychology literature performed by Spini, Elcheroth, \& Figini (2008), which showed that personality was a main field of social psychology analysing individual development. On the sociological pole, 
we find other concepts like poverty, migration, the labour market, education, welfare, families, work, transition, and life course. On the top of Figure 2, we find concepts associated with the elderly: frailty, life span, health care, cognition, and pension. We clearly find here main issues related to the gerontological field and the overarching theme of frailty, which can be defined as a health syndrome of decreased reserves and resistance to stressors, resulting from senescence, which is associated with a lack of resilience that affects individuals' capacity to recover from loss (Spini, Ghisletta, Guilley, \& Lalive d'Epinay, 2007).

The concept of vulnerability, even if it stands closer to the psychological pole, has an intermediate position between the three poles (psychology, sociology, and gerontology). It is associated with the concepts of adaptation, events, trajectories, and flexibility, and the methods of daily diaries and longitudinal studies. Concerning age stages, both childhood and adulthood are closely associated with vulnerability.

\section{Summary and directions for future research}

This paper has two aims. One is to report on the structure that emerges from scientific life course research and related areas. For that purpose, we have focused on scientific journal abstracts of the year 2000 and after. The other aim is to provide a sense of the disciplinary diversity of the field and and to make a brief assessment of the value that the 'vulnerability' concept may have in the study of human lives.

In highlighting the structure in terms of research themes that emerge from scientific life course research, our findings corroborate the argument that psychological and sociological traditions remain separated when it comes to examining issues related to vulnerability-and this is best exemplified by scientific output in life course sociology and life-span psychology (Mayer, 2009); these disciplines structure the two poles of the main axis of the correspondence analysis. The third pole is represented by gerontology, which covers the fields of ageing studies and youth studies, drawing from all the leading disciplines of the social sciences. Among the life stages-childhood, adolescence, adulthood (including midlife), and old age-we found that adulthood was the least invested period of life, whereas younger and older ages were heavily studied. In particular, many life course sociologists and lifespan psychologists have considered early and late adulthood as marked by critical transitions and events (e.g., labour market entry, transition to marriage and parenthood, entry into retirement), but thought of middle adulthood as a less turbulent period. Yet, the 'tripartite' life course is eroding and 'adulthood' as a life stage will need to be re-defined. Lives are increasingly interwoven with one another, life course transitions get postponed, unions dissolve, migration trajectories increase, and generally-with the biographization of the life course-middle adulthood will certainly deserve more attention in the future.

In exploring the emergent structure of a discipline in terms of longitdudinal data and methods, this paper observes a clear divide concerning data and methods employed according to the field of study and the discipline. Prospective longitudinal studies, experimental data, and retrospective reports are clustering around the psychological pole, while household panel data, national surveys, and event history analysis are more specific for the socio-demographic pole. Gerontology appears to be more associated with qualitative methods than other poles: life stories, focus groups, and in-depth interviews. Finally, let us note that longitudinal studies, which clearly form an overarching category, bridge the discursive and theoretical spaces between psychology, gerontology, and sociology, showing that all three disciplines are concerned with longitudinal studies. In this regard, the distinction between panel studies and prospective studies may actually denote only one type of study, that is named differently in the respective traditions.

Regarding the second aim of this review, the assessment of the conceptual value of 'vulnerability', the view is that 'vulnerability' is located in the middle between the three poles of psychology, sociology, and gerontology. According to this view, vulnerability is a major concept for interdisciplinary research and potential theory development. Not only is it not yet part of the intellectual territory of any particular discipline, but also, given its closeness to the neglected middleadulthood life stage, it is a good concept with which to start re-thinking the adult life stage. On the basis of the evidence reviewed above, we argue that longitudinal and life course studies might gain from 
orienting their empirical work towards vulnerability, for at least four key reasons.

a) First, vulnerability is a micro as well as a macro concept. We can talk about individual vulnerabilities and population vulnerabilities. It also allows us to model population behaviour as individual and group responses to structural forces (e.g., changed risk structures) and normative pressures. Central to the concept of vulnerability is the idea of how individuals, groups, and entire populations can adapt to life circumstances, overcome adversities, or recover from them by making use of resources they have or that are made accessible to them. As such, adopting the vulnerability concept can help bridge the disciplinary divide between, in particular, psychological life-span and sociological life course research, and can enhance the perspectives also of demographic researchers by providing a balanced approach integrating individual, group, and macro frames.

b) Second, vulnerability has a static and a dynamic dimension (Spini et al., 2013). Its dynamic dimension provides social scientists with a heuristic to deal with dominant claims, mainly from life course sociologists, that human lives have become de-institutionalized through the internalization of rules and norms of conduct and behaviour. If structural contexts (institutional conditions) are shaping individual cognitive biographical scripts that guide behaviour and that exert more and more impact within individuals as they advance in age (Kohli, 2007), the study of vulnerability allows a dynamic multi-level approach. For instance, various demographic behaviours (e.g., fertility, mortality, and migration) can be modelled by assigning timevarying, life course, and group-specific weights to individual characteristics, ideational factors, and institutional conditions.

c) Third, analysing different forms of behaviour (social, economic, and demographic) and their outcomes benefits from the increasing availability of longitudinal individual-level data covering multiple life-stages and life-domains (e.g., education, work, family, retirement, and health). Though not exhaustive, various countries provide longitudinal data for cross-national comparison, such as Great Britain (BHPS-British Household Panel), Germany (GSOEP-German Socio-economic Panel), Switzerland (SHP-Swiss Household Panel), and the United States (The Panel Study of Income Dynamics, PSID). Here, the 'vulnerability' concept may prove a useful tool for a two- to three-country comparison rather than a simplified tool often required to enable aggregating a larger number of institutional regime types. Vulnerability may be modelled to develop country-specific causal effects with the purpose to propose preventive policy implications and recommendations.

d) Fourth, vulnerability is commonly researched across disciplines. Health topics emerged most recently, which are closely related to morbidity and mortality. Main emerging research tracks concern the relationship between early conditions and later life health and mortality, as well as the variation of health of specific sub-groups in the population, and mortality risks by social class. Integrating the concept of 'vulnerability' in such research streams seems to be more promising than following discipline-specific approaches stressing either individual factors (such as age-specific risks) or structural factors (e.g., socio-economic determinants of health inequalities) for population studies. The fact that vulnerability accumulates across generations (Spini et al., 2007) makes it valuable for research on inter-generational transfers (as well as limited transfer or lack of transfer due to geographical mobility or parents' separation). Inter-generational vulnerability hence can be analysed as an individual or group (i.e., couple, family, or ethnic minority) response to existing social structures and chances of mobility.

\section{Acknowledgements}

This publication benefited from the support of the Swiss National Centre of Competence in Research LIVES - Overcoming vulnerability: life course perspectives, which is financed by the Swiss National Science Foundation. We thank the editor of this journal and the two anonymous reviewers for their valuable comments on earlier versions of the manuscript. 


\section{Appendix A}

List of journals and number of selected articles

\begin{tabular}{|c|c|}
\hline social science and medicine & 646 \\
\hline journal of affective disorders & 332 \\
\hline journal of marriage and family & 308 \\
\hline journal of youth and adolescence & 208 \\
\hline reflections: narratives of professional helping & 199 \\
\hline journal of adolescent health & 195 \\
\hline developmental psychology & 183 \\
\hline personality and individual differences & 162 \\
\hline social indicators research & 158 \\
\hline the journals of gerontology. series b, psychological sciences and social sciences & 153 \\
\hline 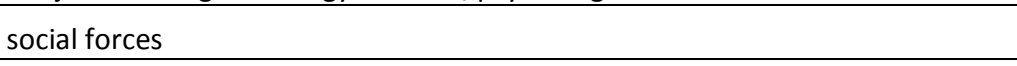 & 148 \\
\hline journal of family psychology & 146 \\
\hline journal of family issues & 143 \\
\hline journal of psychosomatic research & 136 \\
\hline children and youth services review & 135 \\
\hline social science research & 127 \\
\hline journal of personality and social psychology & 116 \\
\hline social science quarterly & 113 \\
\hline qualitative inquiry & 112 \\
\hline health psychology (hillsdale, n.j.) & 112 \\
\hline demography & 108 \\
\hline journal of adolescence & 103 \\
\hline european sociological review & 96 \\
\hline journal of applied psychology & 95 \\
\hline journal of health and social behavior & 93 \\
\hline journal of abnormal psychology (1965) & 90 \\
\hline american sociological review & 90 \\
\hline psychology and aging & 89 \\
\hline forum qualitative sozialforschung/forum: qualitative social research & 88 \\
\hline journal of educational psychology & 88 \\
\hline the gerontologist & 85 \\
\hline ageing and society & 85 \\
\hline journal of research on adolescence & 83 \\
\hline international journal of behavioral development (print) & 76 \\
\hline social science and medicine (1982) & 71 \\
\hline sociology of health and illness & 71 \\
\hline journal of traumatic stress & 70 \\
\hline research on aging & 69 \\
\hline sex roles: a journal of research & 69 \\
\hline demographic research & 68 \\
\hline journal of social and personal relationships & 67 \\
\hline journals of gerontology series b: psychological sciences and social sciences & 67 \\
\hline
\end{tabular}




\begin{tabular}{|c|c|}
\hline aids care & 66 \\
\hline journal of personality & 65 \\
\hline american journal of community psychology & 63 \\
\hline sociological research online & 61 \\
\hline sociology of education & 60 \\
\hline family relations & 60 \\
\hline industrial and labor relations review & 57 \\
\hline aids and behavior & 57 \\
\hline women's studies international forum & 56 \\
\hline american journal of sociology & 54 \\
\hline british journal of health psychology & 54 \\
\hline journal of social and clinical psychology & 54 \\
\hline journal of adolescent research & 53 \\
\hline social problems & 52 \\
\hline journal of occupational and organizational psychology & 52 \\
\hline sex roles & 52 \\
\hline international journal of sociology & 51 \\
\hline the sociological quarterly & 51 \\
\hline labour & 50 \\
\hline international journal of aging and human development & 50 \\
\hline sociology & 50 \\
\hline families in society & 50 \\
\hline the british journal of social work & 49 \\
\hline marriage and family review & 49 \\
\hline british journal of educational psychology & 49 \\
\hline journal of family and economic issues & 48 \\
\hline the journal of development studies & 47 \\
\hline population research and policy review & 47 \\
\hline gender and education & 47 \\
\hline journal of youth studies & 47 \\
\hline kolner zeitschrift fur soziologie und sozialpsychologie & 47 \\
\hline work and stress & 46 \\
\hline american behavioral scientist & 46 \\
\hline british journal of sociology of education & 46 \\
\hline journal of biosocial science & 46 \\
\hline journal of personality disorders & 45 \\
\hline journal of aging and health & 45 \\
\hline journal of counseling psychology & 45 \\
\hline qualitative research & 45 \\
\hline journal of applied developmental psychology & 44 \\
\hline reflections & 44 \\
\hline population studies & 44 \\
\hline journal of behavioral medicine & 43 \\
\hline family process & 43 \\
\hline sotsiologicheskie issledovaniya & 43 \\
\hline
\end{tabular}




\begin{tabular}{|c|c|}
\hline european journal of population/revue europeenne de demographie & 42 \\
\hline zeitschrift fur soziologie & 42 \\
\hline psychology, health and medicine & 42 \\
\hline journal of ethnic and migration studies & 42 \\
\hline women and health & 41 \\
\hline journal of aging studies & 41 \\
\hline quality and quantity & 41 \\
\hline the journal of socio-economics & 41 \\
\hline youth and society & 41 \\
\hline world development & 41 \\
\hline journal of family violence & 41 \\
\hline social service review & 41 \\
\hline social work research & 40 \\
\hline international journal of social research methodology & 39 \\
\hline journal of comparative family studies & 39 \\
\hline historical social research/historische sozialforschung & 39 \\
\hline sociological methods and research & 39 \\
\hline journal of social history & 38 \\
\hline journal of contemporary ethnography & 38 \\
\hline research on social work practice & 38 \\
\hline advances in life course research & 38 \\
\hline social behavior and personality & 37 \\
\hline work, employment and society & 37 \\
\hline journal of sociology and social welfare & 37 \\
\hline sociological perspectives & 37 \\
\hline memory and cognition & 36 \\
\hline race, ethnicity and education & 36 \\
\hline qualitative social work & 36 \\
\hline research in social stratification and mobility & 35 \\
\hline gender, place and culture & 35 \\
\hline social psychology quarterly & 35 \\
\hline canadian journal on aging/la revue canadienne du vieillissement & 35 \\
\hline british journal of clinical psychology & 34 \\
\hline the annals of the american academy of political and social science & 34 \\
\hline psychosomatics (washington, dc) & 34 \\
\hline journal of anxiety disorders & 34 \\
\hline journal of community and applied social psychology & 34 \\
\hline industrial relations & 33 \\
\hline journal of divorce and remarriage & 33 \\
\hline signs & 33 \\
\hline health & 33 \\
\hline health and social care in the community & 33 \\
\hline adolescence & 33 \\
\hline international migration review & 32 \\
\hline suicide and life-threatening behavior & 32 \\
\hline
\end{tabular}




\begin{tabular}{|c|c|}
\hline revista espanola de investigaciones sociologicas & 32 \\
\hline deviant behavior & 32 \\
\hline sociological quarterly & 31 \\
\hline sociological spectrum & 31 \\
\hline studies in symbolic interaction & 31 \\
\hline stress and health & 31 \\
\hline international migration & 30 \\
\hline longitudinal surveys of australian youth & 30 \\
\hline international journal of intercultural relations & 30 \\
\hline journal of health psychology & 30 \\
\hline psychological assessment & 30 \\
\hline journal of social policy & 30 \\
\hline psychopathology & 30 \\
\hline qualitative report & 29 \\
\hline child and family social work & 29 \\
\hline european psychologist & 29 \\
\hline ethnography & 29 \\
\hline sociology of sport journal & 29 \\
\hline social identities & 28 \\
\hline the sociological review & 28 \\
\hline social work in health care & 28 \\
\hline work and occupations & 28 \\
\hline aids education and prevention & 28 \\
\hline sociological forum & 28 \\
\hline women's studies quarterly & 27 \\
\hline acta sociologica & 27 \\
\hline culture and psychology & 27 \\
\hline schmollers jahrbuch & 27 \\
\hline anthropology and medicine & 27 \\
\hline women's history review & 27 \\
\hline qualitative sociology & 27 \\
\hline journal of aggression, maltreatment and trauma & 27 \\
\hline international journal of social welfare & 27 \\
\hline applied cognitive psychology & 27 \\
\hline gender and society & 27 \\
\hline canadian studies in population & 27 \\
\hline european journal of social psychology & 26 \\
\hline
\end{tabular}


Appendix B

SIMPLE CORRESPONDENCE ANALYSIS

EIGENVALUES

COMPUTATIONS PRECISION SUMMARY: TRACE BEFORE DIAGONALISATION. 0.7277

SUM OF EIGENVALUES.

0.7277

FIRST 5 EIGENVALUES

\begin{tabular}{|c|c|c|c|c|c|c|c|c|}
\hline NUMBER & $\begin{array}{l}\text { EIGEN- } \\
\text { VALUE }\end{array}$ & $\begin{array}{l}\text { PERCENT- } \\
\text { AGE }\end{array}$ & \multicolumn{2}{|c|}{$\begin{array}{l}\text { CUMULATED } \\
\text { PERCENTAGE }\end{array}$} & & & & \\
\hline 1 & 0.4909 & 67.46 & \multicolumn{2}{|c|}{67.46} & & & & \\
\hline 2 & 0.1094 & 15.03 & \multicolumn{2}{|c|}{82.49} & & & & \\
\hline 3 & 0.066 & 9.08 & \multicolumn{2}{|c|}{91.57} & & & & \\
\hline 4 & 0.0343 & 4.71 & \multicolumn{2}{|c|}{96.28} & & & & \\
\hline 5 & 0.0271 & 3.72 & \multicolumn{2}{|c|}{100} & & & & \\
\hline \multicolumn{9}{|c|}{ Khi-2 TEST FOR AXIS CHOICE } \\
\hline \multicolumn{9}{|c|}{ (USING USUAL THRESHOLD, YOU CAN GO TO THE FIRST TEST-VALUE > 2.0) } \\
\hline NUMBER OF AXES & $\begin{array}{l}\text { STAT } \\
\text { KHI2 }\end{array}$ & $\begin{array}{l}\text { DEG. OF } \\
\text { FREEDOM }\end{array}$ & $\begin{array}{l}\text { PROB. } \\
X>K H I 2\end{array}$ & $\begin{array}{l}\text { TEST } \\
\text { VALUE }\end{array}$ & & & & \\
\hline 1 & 2571.61 & 272 & 0 & -41.11 & * & & & \\
\hline 2 & 1383.57 & 201 & 0 & -28.22 & $*$ & & & \\
\hline \multicolumn{9}{|c|}{ COORDINATES, CONTRIBUTIONS OF FREQUENCIES ON AXES 1 TO 2} \\
\hline \multicolumn{9}{|c|}{\begin{tabular}{l|l|l|l|l} 
ACTIVE & & & & \\
FREQUENCIES & & & & \\
\end{tabular}} \\
\hline \multicolumn{3}{|c|}{ FREQUENCIES } & \multicolumn{2}{|c|}{ COORDINATES } & \multicolumn{2}{|c|}{$\begin{array}{l}\text { CONTRIBU- } \\
\text { TIONS }\end{array}$} & \multicolumn{2}{|c|}{$\begin{array}{l}\text { SQUARED } \\
\text { COSINES }\end{array}$} \\
\hline $\begin{array}{l}\text { IDEN - SHORT } \\
\text { LABEL }\end{array}$ & REL.WT & DISTO & 1 & 2 & 1 & 2 & 1 & 2 \\
\hline $\mathrm{m} 1-1$ & 36.45 & 0.74 & 0.84 & 0.18 & 52.60 & 10.90 & 0.96 & 0.04 \\
\hline$m 2-2$ & 27.20 & 0.75 & -0.81 & 0.25 & 36.00 & 15.90 & 0.87 & 0.09 \\
\hline$m 3-3$ & 17.80 & 0.33 & -0.34 & -0.27 & 4.30 & 12.30 & 0.35 & 0.23 \\
\hline$m 4-4$ & 3.90 & 1.78 & -0.91 & 0.27 & 6.60 & 2.50 & 0.47 & 0.04 \\
\hline m5 - 5 & 6.43 & 0.91 & 0.19 & -0.74 & 0.50 & 31.90 & 0.04 & 0.60 \\
\hline $\mathrm{m} 7-7$ & 8.22 & 0.82 & -0.04 & -0.59 & 0.00 & 26.50 & 0.00 & 0.43 \\
\hline \multicolumn{9}{|c|}{ SUPPLEMENTARY FREQUENCIES } \\
\hline \multicolumn{3}{|c|}{ FREQUENCIES } & \multicolumn{2}{|c|}{ COORDINATES } & \multicolumn{2}{|c|}{$\begin{array}{l}\text { CONTRIBU- } \\
\text { TIONS }\end{array}$} & \multicolumn{2}{|c|}{$\begin{array}{l}\text { SQUARED } \\
\text { COSINES }\end{array}$} \\
\hline $\begin{array}{l}\text { IDEN - SHORT } \\
\text { LABEL }\end{array}$ & REL.WT & DISTO & 1 & 2 & 1 & 2 & 1 & 2 \\
\hline$m 1-2000$ & 3.32 & 0.89 & -0.49 & -0.07 & 0.00 & 0.00 & 0.27 & 0.01 \\
\hline$m 2-2001$ & 7.03 & 0.34 & 0.00 & 0.14 & 0.00 & 0.00 & 0.00 & 0.06 \\
\hline$m 3-2002$ & 6.76 & 0.22 & -0.05 & -0.05 & 0.00 & 0.00 & 0.01 & 0.01 \\
\hline m4 - 2003 & 7.25 & 0.26 & -0.12 & 0.05 & 0.00 & 0.00 & 0.05 & 0.01 \\
\hline
\end{tabular}




\begin{tabular}{|c|c|c|c|c|c|c|c|c|}
\hline m5 - 2004 & 8.74 & 0.16 & 0.05 & -0.02 & 0.00 & 0.00 & 0.02 & 0.00 \\
\hline$m 6-2005$ & 9.73 & 0.12 & 0.05 & -0.04 & 0.00 & 0.00 & 0.02 & 0.02 \\
\hline$m 7-2006$ & 11.47 & 0.16 & -0.03 & -0.04 & 0.00 & 0.00 & 0.01 & 0.01 \\
\hline$m 8-2007$ & 12.15 & 0.11 & 0.02 & -0.01 & 0.00 & 0.00 & 0.00 & 0.00 \\
\hline m9 - 2008 & 12.92 & 0.16 & 0.11 & 0.02 & 0.00 & 0.00 & 0.07 & 0.00 \\
\hline m10 - 2009 & 9.82 & 0.30 & -0.31 & -0.17 & 0.00 & 0.00 & 0.31 & 0.10 \\
\hline m11 - 2010 & 13.21 & 0.23 & 0.23 & 0.01 & 0.00 & 0.00 & 0.24 & 0.00 \\
\hline$m 6-6$ & 2.41 & 5.43 & -0.21 & -0.70 & 0.00 & 0.00 & 0.01 & 0.09 \\
\hline \multicolumn{9}{|c|}{ COORDINATES, CONTRIBUTIONS AND SQUARED COSINES OF CASES } \\
\hline \multicolumn{9}{|c|}{\begin{tabular}{|l|l|l|l} 
ACTIVE CASES (AXES 1 TO 2) & & &
\end{tabular}} \\
\hline \multicolumn{3}{|c|}{ CASES } & \multicolumn{2}{|c|}{ COORDINATES } & \multicolumn{2}{|c|}{ CONTRIBUTIONS } & \multicolumn{2}{|c|}{$\begin{array}{l}\text { SQUARED } \\
\text { COSINES }\end{array}$} \\
\hline IDENTIFIER & REL.WT. & DISTO & 1 & 2 & 1 & 2 & 1 & 2 \\
\hline adolescent health & 3.47 & 1.01 & -0.45 & -0.31 & 1.40 & 3.00 & 0.20 & 0.09 \\
\hline anxiety disorder & 1.29 & 1.04 & 0.96 & 0.28 & 2.40 & 0.90 & 0.88 & 0.08 \\
\hline bipolar disorder & 1.72 & 1.52 & 1.13 & 0.49 & 4.50 & 3.80 & 0.84 & 0.16 \\
\hline black women & 0.52 & 1.19 & -0.91 & 0.47 & 0.90 & 1.00 & 0.70 & 0.19 \\
\hline breast cancer & 1.30 & 0.52 & 0.54 & 0.25 & 0.80 & 0.70 & 0.55 & 0.12 \\
\hline coping strategies & 1.20 & 0.74 & 0.85 & 0.08 & 1.80 & 0.10 & 0.98 & 0.01 \\
\hline depressive disorder & 0.99 & 1.47 & 1.13 & 0.42 & 2.50 & 1.60 & 0.86 & 0.12 \\
\hline depressive episode & 1.21 & 1.36 & 1.08 & 0.39 & 2.90 & 1.70 & 0.86 & 0.11 \\
\hline $\begin{array}{l}\text { depressive } \\
\text { symptoms }\end{array}$ & 9.87 & 0.36 & 0.45 & -0.37 & 4.00 & 12.10 & 0.56 & 0.38 \\
\hline economic resources & 0.48 & 0.79 & -0.83 & 0.21 & 0.70 & 0.20 & 0.88 & 0.06 \\
\hline $\begin{array}{l}\text { education } \\
\text { longitudinal }\end{array}$ & 0.55 & 0.76 & -0.76 & 0.19 & 0.70 & 0.20 & 0.76 & 0.05 \\
\hline $\begin{array}{l}\text { educational } \\
\text { attainment }\end{array}$ & 2.53 & 0.23 & -0.45 & 0.09 & 1.10 & 0.20 & 0.90 & 0.04 \\
\hline $\begin{array}{l}\text { educational } \\
\text { expectations }\end{array}$ & 0.50 & 1.99 & -0.67 & -0.26 & 0.50 & 0.30 & 0.23 & 0.04 \\
\hline $\begin{array}{l}\text { european } \\
\text { community }\end{array}$ & 0.62 & 1.27 & -1.00 & 0.37 & 1.30 & 0.80 & 0.79 & 0.11 \\
\hline european countries & 0.46 & 0.91 & -0.82 & 0.29 & 0.60 & 0.40 & 0.74 & 0.09 \\
\hline family background & 0.62 & 0.54 & -0.71 & 0.09 & 0.60 & 0.10 & 0.92 & 0.02 \\
\hline family formation & 0.54 & 1.15 & -0.90 & 0.48 & 0.90 & 1.10 & 0.70 & 0.20 \\
\hline family history & 0.77 & 0.95 & 0.91 & 0.36 & 1.30 & 0.90 & 0.86 & 0.13 \\
\hline family life & 0.64 & 0.34 & -0.54 & 0.02 & 0.40 & 0.00 & 0.85 & 0.00 \\
\hline family structure & 1.92 & 0.55 & -0.71 & 0.07 & 2.00 & 0.10 & 0.91 & 0.01 \\
\hline force participation & 0.72 & 1.19 & -0.96 & 0.49 & 1.40 & 1.60 & 0.78 & 0.20 \\
\hline health service & 1.18 & 0.69 & -0.03 & -0.67 & 0.00 & 4.80 & 0.00 & 0.65 \\
\hline higher education & 1.34 & 0.65 & -0.69 & 0.08 & 1.30 & 0.10 & 0.74 & 0.01 \\
\hline household income & 0.69 & 0.63 & -0.75 & 0.07 & 0.80 & 0.00 & 0.89 & 0.01 \\
\hline human capital & 1.61 & 0.79 & -0.78 & 0.39 & 2.00 & 2.30 & 0.77 & 0.20 \\
\hline
\end{tabular}




\begin{tabular}{|c|c|c|c|c|c|c|c|c|}
\hline income dynamics & 1.59 & 0.78 & -0.81 & 0.11 & 2.10 & 0.20 & 0.84 & 0.01 \\
\hline income inequality & 0.60 & 1.27 & -0.96 & 0.26 & 1.10 & 0.40 & 0.73 & 0.05 \\
\hline $\begin{array}{l}\text { intergenerational } \\
\text { transmiss. }\end{array}$ & 0.56 & 0.68 & -0.64 & 0.38 & 0.50 & 0.70 & 0.60 & 0.22 \\
\hline job demands & 0.50 & 1.46 & 1.12 & 0.44 & 1.30 & 0.90 & 0.86 & 0.14 \\
\hline labor force & 1.56 & 0.73 & -0.76 & 0.16 & 1.80 & 0.40 & 0.80 & 0.04 \\
\hline labor market & 4.81 & 1.08 & -0.96 & 0.34 & 9.00 & 5.20 & 0.86 & 0.11 \\
\hline life expectancy & 0.48 & 2.35 & -0.61 & -0.39 & 0.40 & 0.60 & 0.16 & 0.06 \\
\hline living arrangements & 0.72 & 1.09 & -0.66 & -0.41 & 0.60 & 1.10 & 0.40 & 0.15 \\
\hline major depression & 2.38 & 1.37 & 1.09 & 0.43 & 5.70 & 3.90 & 0.86 & 0.13 \\
\hline married women & 0.66 & 0.67 & -0.72 & 0.22 & 0.70 & 0.30 & 0.76 & 0.08 \\
\hline mean age & 1.55 & 0.73 & 0.58 & -0.38 & 1.00 & 2.10 & 0.46 & 0.20 \\
\hline mental health & 6.87 & 0.26 & 0.09 & -0.49 & 0.10 & 15.10 & 0.03 & 0.93 \\
\hline mental illness & 0.69 & 0.36 & -0.32 & 0.01 & 0.10 & 0.00 & 0.28 & 0.00 \\
\hline middle class & 1.13 & 0.76 & -0.70 & 0.18 & 1.10 & 0.30 & 0.64 & 0.04 \\
\hline negative affect & 1.79 & 0.93 & 0.89 & -0.06 & 2.90 & 0.10 & 0.85 & 0.00 \\
\hline negative effect & 1.68 & 0.25 & -0.40 & 0.22 & 0.60 & 0.80 & 0.66 & 0.21 \\
\hline outcome measures & 0.85 & 0.91 & 0.91 & 0.25 & 1.40 & 0.50 & 0.91 & 0.07 \\
\hline parental divorce & 0.54 & 0.66 & -0.63 & 0.07 & 0.40 & 0.00 & 0.61 & 0.01 \\
\hline partially mediated & 0.85 & 0.67 & 0.75 & 0.01 & 1.00 & 0.00 & 0.85 & 0.00 \\
\hline $\begin{array}{l}\text { personality } \\
\text { disorder }\end{array}$ & 1.55 & 1.47 & 1.11 & 0.48 & 3.90 & 3.30 & 0.83 & 0.16 \\
\hline personality traits & 1.04 & 0.67 & 0.81 & 0.04 & 1.40 & 0.00 & 0.97 & 0.00 \\
\hline positive effect & 1.57 & 0.24 & -0.40 & 0.19 & 0.50 & 0.50 & 0.65 & 0.15 \\
\hline $\begin{array}{l}\text { posttraumatic } \\
\text { stress }\end{array}$ & 0.95 & 1.54 & 1.15 & 0.47 & 2.50 & 1.90 & 0.85 & 0.14 \\
\hline $\begin{array}{l}\text { prospective } \\
\text { memory }\end{array}$ & 0.91 & 1.27 & 1.07 & 0.19 & 2.10 & 0.30 & 0.91 & 0.03 \\
\hline $\begin{array}{l}\text { psychological } \\
\text { association }\end{array}$ & 0.79 & 1.74 & 1.20 & 0.55 & 2.30 & 2.20 & 0.83 & 0.17 \\
\hline rating scale & 0.58 & 1.43 & 1.12 & 0.42 & 1.50 & 0.90 & 0.88 & 0.12 \\
\hline rural areas & 0.43 & 1.23 & -0.60 & -0.24 & 0.30 & 0.20 & 0.29 & 0.05 \\
\hline single mothers & 0.67 & 1.44 & -0.93 & 0.65 & 1.20 & 2.60 & 0.60 & 0.29 \\
\hline social assistance & 0.42 & 1.55 & -1.01 & 0.43 & 0.90 & 0.70 & 0.66 & 0.12 \\
\hline social capital & 2.64 & 0.52 & -0.58 & 0.01 & 1.80 & 0.00 & 0.65 & 0.00 \\
\hline social change & 0.61 & 0.58 & -0.59 & 0.17 & 0.40 & 0.20 & 0.60 & 0.05 \\
\hline social class & 1.35 & 0.36 & -0.40 & -0.14 & 0.40 & 0.20 & 0.44 & 0.05 \\
\hline social networks & 2.04 & 0.21 & -0.32 & -0.23 & 0.40 & 1.00 & 0.50 & 0.26 \\
\hline social services & 0.24 & 0.97 & -0.45 & -0.67 & 0.10 & 1.00 & 0.21 & 0.46 \\
\hline social support & 6.65 & 0.33 & 0.36 & -0.33 & 1.70 & 6.60 & 0.38 & 0.33 \\
\hline $\begin{array}{l}\text { socioeconomic } \\
\text { status }\end{array}$ & 2.70 & 0.16 & -0.16 & -0.33 & 0.10 & 2.70 & 0.15 & 0.67 \\
\hline stress disorder & 0.91 & 1.53 & 1.13 & 0.50 & 2.40 & 2.10 & 0.83 & 0.16 \\
\hline suicidal behavior & 0.55 & 1.11 & 0.93 & 0.20 & 1.00 & 0.20 & 0.79 & 0.04 \\
\hline
\end{tabular}




\begin{tabular}{|c|c|c|c|c|c|c|c|c|}
\hline suicide attempts & 1.11 & 0.57 & 0.65 & 0.00 & 1.00 & 0.00 & 0.73 & 0.00 \\
\hline symptom severity & 0.48 & 1.46 & 1.10 & 0.47 & 1.20 & 1.00 & 0.84 & 0.15 \\
\hline united states & 2.77 & 0.31 & -0.49 & -0.12 & 1.30 & 0.40 & 0.77 & 0.05 \\
\hline welfare recipients & 0.35 & 0.55 & -0.62 & 0.17 & 0.30 & 0.10 & 0.70 & 0.05 \\
\hline welfare state & 0.84 & 0.98 & -0.88 & 0.34 & 1.30 & 0.90 & 0.79 & 0.12 \\
\hline west germany & 0.56 & 2.55 & -0.85 & 0.30 & 0.80 & 0.50 & 0.29 & 0.04 \\
\hline young men & 0.75 & 0.52 & -0.62 & -0.10 & 0.60 & 0.10 & 0.75 & 0.02 \\
\hline \multicolumn{9}{|c|}{ SUPPLEMENTARY CASES (AXES 1 TO 2) } \\
\hline \multicolumn{3}{|c|}{ CASES } & \multicolumn{2}{|c|}{ COORDINATES } & \multicolumn{2}{|c|}{ CONTRIBUTIONS } & \multicolumn{2}{|c|}{$\begin{array}{c}\text { SQUARED } \\
\text { COSINES }\end{array}$} \\
\hline IDENTIFIER & REL.WT. & DISTO & 1 & 2 & 1 & 2 & 1 & 2 \\
\hline adaptation & 3.04 & 0.05 & 0.18 & -0.05 & 0.00 & 0.00 & 0.69 & 0.05 \\
\hline adolescence & 44.33 & 1.86 & -0.02 & -0.59 & 0.00 & 0.00 & 0.00 & 0.19 \\
\hline adult & 27.77 & 0.31 & 0.04 & -0.45 & 0.00 & 0.00 & 0.01 & 0.65 \\
\hline anxieties & 9.25 & 0.74 & 0.84 & 0.15 & 0.00 & 0.00 & 0.95 & 0.03 \\
\hline biographical & 5.36 & 0.45 & -0.44 & -0.08 & 0.00 & 0.00 & 0.44 & 0.01 \\
\hline care & 19.17 & 0.77 & -0.10 & -0.75 & 0.00 & 0.00 & 0.01 & 0.74 \\
\hline career & 5.52 & 0.21 & -0.35 & 0.23 & 0.00 & 0.00 & 0.58 & 0.26 \\
\hline caregiver & 7.48 & 3.15 & 0.06 & -1.10 & 0.00 & 0.00 & 0.00 & 0.38 \\
\hline childhood & 9.16 & 0.06 & 0.10 & -0.05 & 0.00 & 0.00 & 0.18 & 0.03 \\
\hline clinical & 9.72 & 0.55 & 0.70 & 0.13 & 0.00 & 0.00 & 0.89 & 0.03 \\
\hline cognition & 11.17 & 1.28 & 0.53 & -0.54 & 0.00 & 0.00 & 0.22 & 0.23 \\
\hline cohort & 9.95 & 0.11 & -0.16 & -0.24 & 0.00 & 0.00 & 0.24 & 0.52 \\
\hline coping & 9.01 & 0.58 & 0.76 & 0.07 & 0.00 & 0.00 & 0.99 & 0.01 \\
\hline cross-country & 0.64 & 0.41 & -0.26 & -0.30 & 0.00 & 0.00 & 0.17 & 0.22 \\
\hline cross-cultural & 0.44 & 0.36 & 0.50 & 0.21 & 0.00 & 0.00 & 0.68 & 0.13 \\
\hline cross-section & 1.25 & 0.09 & 0.26 & 0.05 & 0.00 & 0.00 & 0.76 & 0.02 \\
\hline death & 4.32 & 0.80 & -0.19 & -0.51 & 0.00 & 0.00 & 0.05 & 0.33 \\
\hline demographic & 5.29 & 0.51 & -0.13 & -0.12 & 0.00 & 0.00 & 0.04 & 0.03 \\
\hline depression & 40.75 & 0.49 & 0.70 & -0.02 & 0.00 & 0.00 & 1.00 & 0.00 \\
\hline disorder & 15.92 & 1.09 & 0.98 & 0.32 & 0.00 & 0.00 & 0.88 & 0.10 \\
\hline divorce & 6.99 & 0.51 & -0.63 & 0.31 & 0.00 & 0.00 & 0.78 & 0.19 \\
\hline economy & 14.04 & 0.68 & -0.78 & 0.23 & 0.00 & 0.00 & 0.89 & 0.08 \\
\hline education & 27.88 & 0.26 & -0.50 & -0.03 & 0.00 & 0.00 & 0.97 & 0.00 \\
\hline ehist & 2.10 & 1.60 & -0.93 & 0.40 & 0.00 & 0.00 & 0.54 & 0.10 \\
\hline elderly & 4.01 & 2.93 & 0.04 & -1.01 & 0.00 & 0.00 & 0.00 & 0.35 \\
\hline episode & 4.92 & 0.74 & 0.84 & 0.17 & 0.00 & 0.00 & 0.96 & 0.04 \\
\hline ethnographic & 2.31 & 0.84 & -0.75 & 0.16 & 0.00 & 0.00 & 0.67 & 0.03 \\
\hline event & 10.52 & 0.05 & 0.20 & 0.03 & 0.00 & 0.00 & 0.83 & 0.02 \\
\hline face-to-face & 0.47 & 1.06 & 0.21 & -0.66 & 0.00 & 0.00 & 0.04 & 0.41 \\
\hline families & 46.34 & 0.12 & -0.30 & -0.01 & 0.00 & 0.00 & 0.74 & 0.00 \\
\hline fatherhood & 1.05 & 0.77 & -0.65 & 0.50 & 0.00 & 0.00 & 0.54 & 0.32 \\
\hline
\end{tabular}




\begin{tabular}{|c|c|c|c|c|c|c|c|c|}
\hline fertility & 4.19 & 7.89 & -0.95 & 0.54 & 0.00 & 0.00 & 0.12 & 0.04 \\
\hline flexibility & 1.22 & 0.11 & -0.08 & 0.30 & 0.00 & 0.00 & 0.06 & 0.80 \\
\hline follow-up & 6.62 & 0.45 & 0.66 & -0.12 & 0.00 & 0.00 & 0.96 & 0.03 \\
\hline frail & 0.87 & 3.41 & -0.24 & -1.02 & 0.00 & 0.00 & 0.02 & 0.30 \\
\hline graduate & 1.39 & 0.40 & -0.45 & 0.26 & 0.00 & 0.00 & 0.50 & 0.18 \\
\hline health & 57.61 & 0.41 & -0.06 & -0.55 & 0.00 & 0.00 & 0.01 & 0.74 \\
\hline hiv-related & 1.69 & 0.82 & 0.14 & -0.33 & 0.00 & 0.00 & 0.02 & 0.14 \\
\hline hospital & 4.59 & 0.42 & 0.34 & -0.40 & 0.00 & 0.00 & 0.27 & 0.39 \\
\hline household & 10.95 & 0.60 & -0.67 & 0.00 & 0.00 & 0.00 & 0.74 & 0.00 \\
\hline immigration & 8.87 & 1.27 & -0.72 & 0.14 & 0.00 & 0.00 & 0.41 & 0.01 \\
\hline income & 13.20 & 0.51 & -0.65 & -0.03 & 0.00 & 0.00 & 0.82 & 0.00 \\
\hline individual-level & 1.08 & 0.33 & -0.44 & -0.16 & 0.00 & 0.00 & 0.58 & 0.08 \\
\hline labor & 11.72 & 1.03 & -0.91 & 0.41 & 0.00 & 0.00 & 0.80 & 0.16 \\
\hline lifco & 4.99 & 0.41 & -0.61 & -0.14 & 0.00 & 0.00 & 0.91 & 0.05 \\
\hline lifsp & 0.79 & 0.63 & 0.21 & -0.47 & 0.00 & 0.00 & 0.07 & 0.35 \\
\hline lihist & 2.22 & 0.50 & -0.69 & 0.01 & 0.00 & 0.00 & 0.96 & 0.00 \\
\hline listo & 1.22 & 0.37 & 0.03 & -0.45 & 0.00 & 0.00 & 0.00 & 0.55 \\
\hline manic & 1.88 & 1.74 & 1.20 & 0.55 & 0.00 & 0.00 & 0.83 & 0.17 \\
\hline market & 7.03 & 1.05 & -0.95 & 0.36 & 0.00 & 0.00 & 0.86 & 0.12 \\
\hline marriage & 15.29 & 0.58 & -0.60 & 0.32 & 0.00 & 0.00 & 0.62 & 0.18 \\
\hline mental & 10.69 & 0.17 & 0.11 & -0.37 & 0.00 & 0.00 & 0.07 & 0.81 \\
\hline midlife & 1.35 & 1.14 & 0.09 & -0.60 & 0.00 & 0.00 & 0.01 & 0.32 \\
\hline migration & 9.74 & 2.49 & -0.93 & 0.33 & 0.00 & 0.00 & 0.35 & 0.04 \\
\hline narration & 24.76 & 0.36 & -0.44 & -0.05 & 0.00 & 0.00 & 0.54 & 0.01 \\
\hline partnership & 12.07 & 0.05 & 0.08 & -0.06 & 0.00 & 0.00 & 0.15 & 0.07 \\
\hline patient & 20.78 & 0.68 & 0.76 & 0.12 & 0.00 & 0.00 & 0.86 & 0.02 \\
\hline pension & 0.73 & 1.47 & -0.47 & -0.36 & 0.00 & 0.00 & 0.15 & 0.09 \\
\hline personality & 8.77 & 1.07 & 0.99 & 0.28 & 0.00 & 0.00 & 0.92 & 0.07 \\
\hline poverty & 5.86 & 0.88 & -0.77 & 0.01 & 0.00 & 0.00 & 0.67 & 0.00 \\
\hline professionals & 5.30 & 0.29 & -0.31 & -0.34 & 0.00 & 0.00 & 0.33 & 0.39 \\
\hline reports & 24.18 & 0.26 & 0.26 & -0.31 & 0.00 & 0.00 & 0.26 & 0.38 \\
\hline self-report & 5.73 & 0.38 & 0.55 & -0.19 & 0.00 & 0.00 & 0.80 & 0.10 \\
\hline services & 9.50 & 0.61 & -0.15 & -0.70 & 0.00 & 0.00 & 0.04 & 0.82 \\
\hline sociological & 4.86 & 1.35 & -0.93 & 0.42 & 0.00 & 0.00 & 0.64 & 0.13 \\
\hline stress & 16.65 & 0.34 & 0.56 & -0.03 & 0.00 & 0.00 & 0.92 & 0.00 \\
\hline survey & 19.62 & 0.27 & -0.40 & -0.13 & 0.00 & 0.00 & 0.61 & 0.06 \\
\hline trajectories & 7.06 & 0.16 & -0.05 & -0.34 & 0.00 & 0.00 & 0.01 & 0.70 \\
\hline transition & 11.12 & 0.26 & -0.44 & -0.07 & 0.00 & 0.00 & 0.74 & 0.02 \\
\hline treatment & 13.85 & 0.45 & 0.61 & 0.11 & 0.00 & 0.00 & 0.83 & 0.02 \\
\hline uncertain & 1.29 & 0.40 & -0.46 & 0.15 & 0.00 & 0.00 & 0.52 & 0.06 \\
\hline vulnerability & 3.61 & 0.22 & 0.35 & -0.26 & 0.00 & 0.00 & 0.55 & 0.31 \\
\hline wages & 3.75 & 1.43 & -1.03 & 0.53 & 0.00 & 0.00 & 0.74 & 0.20 \\
\hline
\end{tabular}




\begin{tabular}{|c|c|c|c|c|c|c|c|c|}
\hline \multicolumn{3}{|l|}{ CASES } & \multicolumn{2}{|c|}{ COORDINATES } & \multicolumn{2}{|c|}{ CONTRIBUTIONS } & \multicolumn{2}{|c|}{$\begin{array}{l}\text { SQUARED } \\
\text { COSINES }\end{array}$} \\
\hline IDENTIFIER & REL.WT. & DISTO & 1 & 2 & 1 & 2 & 1 & 2 \\
\hline welfare & 7.13 & 0.62 & -0.66 & -0.04 & 0.00 & 0.00 & 0.69 & 0.00 \\
\hline work & 42.69 & 0.16 & -0.33 & 0.05 & 0.00 & 0.00 & 0.68 & 0.02 \\
\hline birth cohort & 0.85 & 0.36 & -0.53 & -0.12 & 0.00 & 0.00 & 0.80 & 0.04 \\
\hline case studies & 0.41 & 0.30 & -0.47 & 0.00 & 0.00 & 0.00 & 0.71 & 0.00 \\
\hline control group & 0.95 & 0.59 & 0.73 & 0.00 & 0.00 & 0.00 & 0.89 & 0.00 \\
\hline daily diary & 0.64 & 0.20 & 0.41 & 0.05 & 0.00 & 0.00 & 0.85 & 0.01 \\
\hline first birth & 0.55 & 6.21 & -0.86 & 0.44 & 0.00 & 0.00 & 0.12 & 0.03 \\
\hline focus group & 0.99 & 0.58 & -0.32 & -0.44 & 0.00 & 0.00 & 0.18 & 0.33 \\
\hline household panel & 1.66 & 0.84 & -0.87 & 0.12 & 0.00 & 0.00 & 0.91 & 0.02 \\
\hline in-depth interviews & 1.07 & 0.35 & -0.38 & -0.18 & 0.00 & 0.00 & 0.40 & 0.09 \\
\hline later life & 0.99 & 4.68 & 0.08 & -1.18 & 0.00 & 0.00 & 0.00 & 0.30 \\
\hline life events & 2.39 & 0.20 & 0.40 & -0.13 & 0.00 & 0.00 & 0.83 & 0.09 \\
\hline logistic regression & 2.75 & 0.52 & 0.05 & -0.63 & 0.00 & 0.00 & 0.01 & 0.76 \\
\hline longitudinal studies & 7.80 & 0.08 & -0.17 & -0.02 & 0.00 & 0.00 & 0.39 & 0.00 \\
\hline multiple regression & 0.89 & 0.27 & 0.46 & -0.24 & 0.00 & 0.00 & 0.77 & 0.22 \\
\hline national longitudinal & 6.75 & 0.55 & -0.58 & -0.04 & 0.00 & 0.00 & 0.60 & 0.00 \\
\hline national survey & 0.86 & 0.60 & -0.69 & 0.09 & 0.00 & 0.00 & 0.80 & 0.01 \\
\hline panel survey & 1.49 & 0.60 & -0.64 & -0.18 & 0.00 & 0.00 & 0.68 & 0.05 \\
\hline prospective cohort & 0.68 & 0.43 & 0.42 & -0.27 & 0.00 & 0.00 & 0.42 & 0.17 \\
\hline $\begin{array}{l}\text { prospective } \\
\text { longitudinal }\end{array}$ & 0.90 & 0.39 & 0.53 & -0.06 & 0.00 & 0.00 & 0.71 & 0.01 \\
\hline prospective studies & 0.49 & 1.04 & 0.96 & 0.32 & 0.00 & 0.00 & 0.89 & 0.10 \\
\hline $\begin{array}{l}\text { qualitative } \\
\text { interviews }\end{array}$ & 0.50 & 0.66 & -0.33 & -0.47 & 0.00 & 0.00 & 0.16 & 0.33 \\
\hline regression analyses & 2.08 & 0.30 & 0.33 & -0.31 & 0.00 & 0.00 & 0.36 & 0.33 \\
\hline $\begin{array}{l}\text { retrospective } \\
\text { reports }\end{array}$ & 0.59 & 0.53 & 0.64 & 0.28 & 0.00 & 0.00 & 0.77 & 0.15 \\
\hline social work & 1.14 & 0.67 & -0.69 & -0.01 & 0.00 & 0.00 & 0.70 & 0.00 \\
\hline $\begin{array}{l}\text { socio-economic } \\
\text { panel }\end{array}$ & 1.05 & 1.03 & -0.85 & 0.06 & 0.00 & 0.00 & 0.70 & 0.00 \\
\hline time series & 1.92 & 0.47 & -0.57 & 0.17 & 0.00 & 0.00 & 0.68 & 0.06 \\
\hline young adulthood & 2.03 & 1.64 & -0.04 & -0.57 & 0.00 & 0.00 & 0.00 & 0.19 \\
\hline young people & 3.43 & 1.55 & -0.39 & -0.50 & 0.00 & 0.00 & 0.10 & 0.16 \\
\hline young women & 1.71 & 0.51 & -0.47 & -0.13 & 0.00 & 0.00 & 0.44 & 0.03 \\
\hline
\end{tabular}


Appendix C

\section{SIMPLE CORRESPONDENCE ANALYSIS}

EIGEN-VALUES

COMPUTATIONS PRECISION SUMMARY: TRACE BEFORE DIAGONALISATION..

0.2511

SUM OF EIGENVALUES.

0.2511

\begin{tabular}{|c|c|c|c|c|c|c|c|c|}
\hline \multicolumn{9}{|c|}{ HISTOGRAM OF THE FIRST 5 EIGENVALUES } \\
\hline \multirow[t]{2}{*}{ NUMBER } & $\begin{array}{l}\text { EIGEN- } \\
\text { VALUE }\end{array}$ & $\begin{array}{c}\text { PERCENT- } \\
\text { AGE }\end{array}$ & $\begin{array}{l}\text { CUMUL- } \\
\text { ATED }\end{array}$ & & & & & \\
\hline & & & $\begin{array}{l}\text { PERCENT- } \\
\text { AGE }\end{array}$ & & & & & \\
\hline 1 & 0.1636 & 65.14 & 65.14 & & & & & \\
\hline 2 & 0.045 & 17.93 & 83.07 & & & & & \\
\hline 3 & 0.0282 & 11.25 & 94.32 & & & & & \\
\hline 4 & 0.0075 & 2.99 & 97.31 & & & & & \\
\hline 5 & 0.0067 & 2.69 & 100 & & & & & \\
\hline \multicolumn{9}{|c|}{ Khi-2 TEST FOR AXIS CHOICE } \\
\hline \multicolumn{9}{|c|}{$\begin{array}{l}\text { (USING USUAL THRESHOLD, YOU CAN GO TO THE FIRST TEST-VALUE } \\
>2.0)\end{array}$} \\
\hline NUMBER & STAT & DEG. OF & PROB. & TEST & & & & \\
\hline OF AXIS & KHI2 & FREEDOM & $X>K H I 2$ & VALUE & & & & \\
\hline 1 & 471.61 & 60 & 0 & -17.01 & $*$ & & & \\
\hline \multicolumn{9}{|c|}{ COORDINATES, CONTRIBUTIONS OF FREQUENCIES ON AXES 1 TO 2} \\
\hline \multicolumn{3}{|c|}{ FREQUENCIES } & \multicolumn{2}{|c|}{ COORDINATES } & \multicolumn{2}{|c|}{$\begin{array}{c}\text { CONTRIBU- } \\
\text { TIONS }\end{array}$} & \multicolumn{2}{|c|}{$\begin{array}{l}\text { SQUARED } \\
\text { COSINES }\end{array}$} \\
\hline $\begin{array}{l}\text { IDEN - SHORT } \\
\text { LABEL }\end{array}$ & REL.WT & DISTO & 1 & 2 & 1 & 2 & 1 & 2 \\
\hline$m 1-1$ & 16.76 & 0.70 & -0.82 & -0.03 & 69.10 & 0.30 & 0.97 & 0.00 \\
\hline$m 2-2$ & 38.16 & 0.08 & 0.26 & 0.08 & 15.40 & 6.00 & 0.81 & 0.09 \\
\hline$m 3-3$ & 21.55 & 0.13 & 0.18 & -0.27 & 4.30 & 35.90 & 0.26 & 0.59 \\
\hline$m 4-4$ & 8.07 & 0.33 & 0.36 & 0.26 & 6.30 & 12.40 & 0.39 & 0.21 \\
\hline$m 5-5$ & 6.33 & 0.22 & -0.03 & -0.36 & 0.00 & 18.50 & 0.00 & 0.60 \\
\hline $\mathrm{m} 7-7$ & 9.13 & 0.39 & -0.29 & 0.36 & 4.70 & 27.00 & 0.22 & 0.34 \\
\hline
\end{tabular}

\begin{tabular}{|c|c|c|c|c|c|c|c|c|}
\hline \multicolumn{9}{|c|}{$\begin{array}{l}\text { SUPPLEMENTARY } \\
\text { FREQUENCIES }\end{array}$} \\
\hline \multicolumn{3}{|l|}{ FREQUENCIES } & \multicolumn{2}{|c|}{ COORDINATES } & \multicolumn{2}{|c|}{$\begin{array}{l}\text { CONTRIBU- } \\
\text { TIONS }\end{array}$} & \multicolumn{2}{|c|}{$\begin{array}{l}\text { SQUARED } \\
\text { COSINES }\end{array}$} \\
\hline $\begin{array}{c}\text { IDEN - SHORT } \\
\text { LABEL }\end{array}$ & REL.WT & DISTO & 1 & 2 & 1 & 2 & 1 & 2 \\
\hline m1 - 2000 & 4.77 & 0.11 & 0.18 & 0.10 & 0.00 & 0.00 & 0.31 & 0.10 \\
\hline$m 2-2001$ & 6.31 & 0.05 & 0.03 & 0.01 & 0.00 & 0.00 & 0.01 & 0.00 \\
\hline m3 - 2002 & 7.16 & 0.08 & 0.03 & 0.02 & 0.00 & 0.00 & 0.02 & 0.00 \\
\hline
\end{tabular}




\begin{tabular}{|c|c|c|c|c|c|c|c|c|}
\hline m4 - 2003 & 7.70 & 0.08 & -0.05 & 0.03 & 0.00 & 0.00 & 0.03 & 0.01 \\
\hline$m 5-2004$ & 8.05 & 0.07 & -0.04 & -0.09 & 0.00 & 0.00 & 0.03 & 0.12 \\
\hline$m 6-2005$ & 9.37 & 0.06 & 0.06 & -0.10 & 0.00 & 0.00 & 0.05 & 0.16 \\
\hline$m 7-2006$ & 10.49 & 0.07 & -0.07 & 0.07 & 0.00 & 0.00 & 0.07 & 0.07 \\
\hline$m 8-2007$ & 12.23 & 0.03 & -0.06 & 0.05 & 0.00 & 0.00 & 0.13 & 0.09 \\
\hline m9- 2008 & 12.01 & 0.06 & 0.00 & -0.01 & 0.00 & 0.00 & 0.00 & 0.00 \\
\hline m10 - 2009 & 11.34 & 0.05 & 0.05 & -0.03 & 0.00 & 0.00 & 0.05 & 0.02 \\
\hline m11 - 2010 & 12.75 & 0.04 & -0.04 & 0.00 & 0.00 & 0.00 & 0.04 & 0.00 \\
\hline$m 6-6$ & 2.19 & 0.39 & -0.17 & 0.09 & 0.00 & 0.00 & 0.07 & 0.02 \\
\hline \multicolumn{9}{|c|}{ COORDINATES, CONTRIBUTIONS AND SQUARED COSINES OF CASES } \\
\hline \multicolumn{9}{|c|}{\begin{tabular}{|l|l|l|l} 
ACTIVE CASES (AXES 1 TO 2) & & & \\
\end{tabular}} \\
\hline \multicolumn{3}{|c|}{ CASES } & \multicolumn{2}{|c|}{ COORDINATES } & \multicolumn{2}{|c|}{ CONTRIBUTIONS } & \multicolumn{2}{|c|}{$\begin{array}{l}\text { SQUARED } \\
\text { COSINES }\end{array}$} \\
\hline IDENTIFIER & REL.WT. & DISTO & 1 & 2 & 1 & 2 & 1 & 2 \\
\hline event history & 4.23 & 0.55 & 0.49 & 0.35 & 6.30 & 11.70 & 0.44 & 0.23 \\
\hline life history & 4.47 & 0.11 & 0.31 & 0.00 & 2.50 & 0.00 & 0.83 & 0.00 \\
\hline life story & 2.47 & 0.50 & -0.38 & -0.57 & 2.20 & 17.50 & 0.29 & 0.64 \\
\hline panel data & 35.91 & 0.10 & 0.30 & -0.09 & 19.30 & 5.90 & 0.89 & 0.08 \\
\hline $\begin{array}{l}\text { survival } \\
\text { analyses }\end{array}$ & 1.67 & 0.87 & -0.80 & 0.14 & 6.60 & 0.80 & 0.74 & 0.02 \\
\hline birth cohort & 1.71 & 0.05 & 0.15 & -0.08 & 0.20 & 0.20 & 0.50 & 0.13 \\
\hline case studies & 0.84 & 0.10 & 0.06 & -0.17 & 0.00 & 0.50 & 0.04 & 0.30 \\
\hline $\begin{array}{l}\text { control gr. } \\
\text { (experiments) }\end{array}$ & 1.91 & 2.07 & -1.33 & -0.32 & 20.80 & 4.30 & 0.86 & 0.05 \\
\hline daily diary & 1.28 & 1.12 & -0.99 & -0.20 & 7.70 & 1.10 & 0.88 & 0.03 \\
\hline focus group & 2.00 & 0.38 & 0.01 & -0.49 & 0.00 & 10.80 & 0.00 & 0.63 \\
\hline $\begin{array}{l}\text { in-depth } \\
\text { interviews }\end{array}$ & 2.15 & 0.18 & 0.02 & -0.39 & 0.00 & 7.10 & 0.00 & 0.81 \\
\hline $\begin{array}{l}\text { longitudinal } \\
\text { studies }\end{array}$ & 29.32 & 0.09 & -0.15 & 0.22 & 4.30 & 32.10 & 0.28 & 0.57 \\
\hline $\begin{array}{l}\text { nationally } \\
\text { representative }\end{array}$ & 4.16 & 0.19 & -0.19 & 0.03 & 0.90 & 0.10 & 0.18 & 0.00 \\
\hline $\begin{array}{l}\text { prospective } \\
\text { longitudinal } \\
\end{array}$ & 1.82 & 1.44 & -1.19 & 0.06 & 15.60 & 0.10 & 0.98 & 0.00 \\
\hline $\begin{array}{l}\text { qualitative } \\
\text { interviews }\end{array}$ & 1.00 & 0.44 & 0.04 & -0.55 & 0.00 & 6.70 & 0.00 & 0.68 \\
\hline $\begin{array}{l}\text { retrospective } \\
\text { reports }\end{array}$ & 1.19 & 2.08 & -1.34 & -0.05 & 13.00 & 0.10 & 0.86 & 0.00 \\
\hline time series & 3.86 & 0.13 & 0.16 & -0.11 & 0.60 & 1.00 & 0.21 & 0.09 \\
\hline
\end{tabular}




\begin{tabular}{|c|c|c|c|c|c|c|c|c|}
\hline \multicolumn{3}{|c|}{ SUPPLEMENTARY CASES (AXES 1 TO 2) } & & & & & & \\
\hline \multicolumn{3}{|c|}{ CASES } & \multicolumn{2}{|c|}{ COORDINATES } & \multicolumn{2}{|c|}{$\begin{array}{c}\text { CONTRIBU- } \\
\text { TIONS }\end{array}$} & \multicolumn{2}{|c|}{$\begin{array}{c}\text { SQUARED } \\
\text { COSINES }\end{array}$} \\
\hline IDENTIFIER & REL.WT. & DISTO & 1 & 2 & 1 & 2 & 1 & 2 \\
\hline adaptation & 6.12 & 0.56 & -0.70 & -0.21 & 0.00 & 0.00 & 0.87 & 0.08 \\
\hline adolescence & 89.35 & 1.75 & -0.64 & 0.73 & 0.00 & 0.00 & 0.24 & 0.31 \\
\hline adult & 55.98 & 0.49 & -0.47 & -0.21 & 0.00 & 0.00 & 0.45 & 0.09 \\
\hline anxieties & 18.65 & 2.60 & -1.55 & -0.09 & 0.00 & 0.00 & 0.93 & 0.00 \\
\hline biographical & 10.80 & 0.23 & 0.09 & -0.39 & 0.00 & 0.00 & 0.04 & 0.66 \\
\hline care & 38.64 & 0.75 & -0.19 & -0.50 & 0.00 & 0.00 & 0.05 & 0.33 \\
\hline career & 11.12 & 0.14 & -0.16 & 0.03 & 0.00 & 0.00 & 0.18 & 0.01 \\
\hline caregiver & 15.07 & 3.23 & -0.19 & -0.98 & 0.00 & 0.00 & 0.01 & 0.30 \\
\hline childhood & 18.47 & 0.46 & -0.65 & -0.04 & 0.00 & 0.00 & 0.92 & 0.00 \\
\hline clinical & 19.60 & 2.10 & -1.34 & -0.28 & 0.00 & 0.00 & 0.86 & 0.04 \\
\hline cognition & 22.51 & 2.02 & -0.94 & -0.58 & 0.00 & 0.00 & 0.43 & 0.17 \\
\hline cohort & 20.06 & 0.12 & -0.27 & -0.12 & 0.00 & 0.00 & 0.61 & 0.12 \\
\hline coping & 18.15 & 2.18 & -1.42 & -0.18 & 0.00 & 0.00 & 0.92 & 0.02 \\
\hline cross-country & 1.28 & 0.31 & -0.04 & -0.54 & 0.00 & 0.00 & 0.01 & 0.94 \\
\hline cross-cultural & 0.89 & 1.56 & -1.11 & -0.27 & 0.00 & 0.00 & 0.79 & 0.05 \\
\hline cross-section & 2.52 & 0.77 & -0.82 & -0.16 & 0.00 & 0.00 & 0.87 & 0.03 \\
\hline death & 8.70 & 0.69 & -0.05 & -0.65 & 0.00 & 0.00 & 0.00 & 0.62 \\
\hline demographic & 10.65 & 0.34 & -0.35 & 0.12 & 0.00 & 0.00 & 0.37 & 0.04 \\
\hline depression & 82.13 & 1.90 & -1.34 & -0.19 & 0.00 & 0.00 & 0.94 & 0.02 \\
\hline disorder & 32.09 & 3.47 & -1.75 & -0.09 & 0.00 & 0.00 & 0.88 & 0.00 \\
\hline divorce & 14.09 & 0.16 & 0.18 & 0.02 & 0.00 & 0.00 & 0.21 & 0.00 \\
\hline economy & 28.30 & 0.19 & 0.37 & 0.06 & 0.00 & 0.00 & 0.72 & 0.02 \\
\hline education & 56.20 & 0.02 & 0.06 & 0.05 & 0.00 & 0.00 & 0.21 & 0.18 \\
\hline elderly & 8.07 & 3.01 & -0.17 & -1.00 & 0.00 & 0.00 & 0.01 & 0.33 \\
\hline ethnographic & 4.66 & 0.40 & 0.37 & -0.20 & 0.00 & 0.00 & 0.35 & 0.10 \\
\hline event & 21.20 & 0.63 & -0.74 & -0.17 & 0.00 & 0.00 & 0.87 & 0.04 \\
\hline face-to-face & 0.95 & 1.35 & -0.55 & -0.54 & 0.00 & 0.00 & 0.22 & 0.22 \\
\hline families & 93.41 & 0.06 & -0.20 & 0.11 & 0.00 & 0.00 & 0.70 & 0.20 \\
\hline fatherhood & 2.12 & 0.37 & 0.12 & 0.24 & 0.00 & 0.00 & 0.04 & 0.15 \\
\hline fertility & 8.44 & 3.40 & 0.53 & 0.61 & 0.00 & 0.00 & 0.08 & 0.11 \\
\hline flexibility & 2.45 & 0.40 & -0.48 & -0.02 & 0.00 & 0.00 & 0.56 & 0.00 \\
\hline follow-up & 13.34 & 1.69 & -1.25 & -0.26 & 0.00 & 0.00 & 0.93 & 0.04 \\
\hline frail & 1.74 & 3.29 & 0.15 & -0.85 & 0.00 & 0.00 & 0.01 & 0.22 \\
\hline graduate & 2.80 & 0.22 & -0.10 & 0.23 & 0.00 & 0.00 & 0.05 & 0.25 \\
\hline health & 116.11 & 0.44 & -0.27 & -0.49 & 0.00 & 0.00 & 0.17 & 0.55 \\
\hline hospital & 9.24 & 0.93 & -0.76 & -0.58 & 0.00 & 0.00 & 0.61 & 0.36 \\
\hline household & 22.07 & 0.15 & 0.32 & -0.15 & 0.00 & 0.00 & 0.67 & 0.15 \\
\hline immigration & 17.87 & 0.38 & 0.32 & 0.14 & 0.00 & 0.00 & 0.27 & 0.05 \\
\hline income & 26.61 & 0.12 & 0.30 & -0.15 & 0.00 & 0.00 & 0.72 & 0.18 \\
\hline
\end{tabular}




\begin{tabular}{|c|c|c|c|c|c|c|c|c|}
\hline individual-level & 2.17 & 0.12 & 0.01 & -0.05 & 0.00 & 0.00 & 0.00 & 0.02 \\
\hline insecure & 2.73 & 0.62 & -0.47 & -0.53 & 0.00 & 0.00 & 0.36 & 0.45 \\
\hline labor & 23.63 & 0.43 & 0.47 & 0.18 & 0.00 & 0.00 & 0.51 & 0.08 \\
\hline lifco & 10.06 & 0.10 & 0.26 & -0.13 & 0.00 & 0.00 & 0.66 & 0.16 \\
\hline lifsp & 1.60 & 0.95 & -0.57 & -0.58 & 0.00 & 0.00 & 0.34 & 0.35 \\
\hline manic & 3.79 & 4.97 & -2.03 & -0.13 & 0.00 & 0.00 & 0.83 & 0.00 \\
\hline market & 14.16 & 0.45 & 0.53 & 0.15 & 0.00 & 0.00 & 0.62 & 0.05 \\
\hline marriage & 30.83 & 0.15 & 0.14 & 0.11 & 0.00 & 0.00 & 0.13 & 0.09 \\
\hline mental & 21.55 & 0.43 & -0.56 & -0.30 & 0.00 & 0.00 & 0.73 & 0.20 \\
\hline midlife & 2.73 & 1.32 & -0.35 & -0.78 & 0.00 & 0.00 & 0.09 & 0.47 \\
\hline migration & 19.64 & 0.93 & 0.56 & 0.23 & 0.00 & 0.00 & 0.34 & 0.06 \\
\hline narration & 49.91 & 0.16 & 0.06 & -0.30 & 0.00 & 0.00 & 0.02 & 0.57 \\
\hline partnership & 24.33 & 0.42 & -0.63 & 0.00 & 0.00 & 0.00 & 0.96 & 0.00 \\
\hline patient & 41.89 & 2.33 & -1.39 & -0.37 & 0.00 & 0.00 & 0.83 & 0.06 \\
\hline pension & 1.47 & 1.22 & 0.21 & -0.41 & 0.00 & 0.00 & 0.04 & 0.14 \\
\hline personality & 17.67 & 3.40 & -1.72 & -0.22 & 0.00 & 0.00 & 0.87 & 0.01 \\
\hline poverty & 11.80 & 0.27 & 0.41 & 0.00 & 0.00 & 0.00 & 0.63 & 0.00 \\
\hline professionals & 10.69 & 0.16 & -0.13 & -0.02 & 0.00 & 0.00 & 0.11 & 0.00 \\
\hline resources & 17.20 & 0.16 & -0.19 & -0.27 & 0.00 & 0.00 & 0.22 & 0.46 \\
\hline risk & 67.97 & 0.57 & -0.69 & 0.01 & 0.00 & 0.00 & 0.85 & 0.00 \\
\hline self-report & 11.54 & 1.37 & -1.16 & -0.09 & 0.00 & 0.00 & 0.99 & 0.01 \\
\hline services & 19.15 & 0.51 & -0.27 & -0.03 & 0.00 & 0.00 & 0.15 & 0.00 \\
\hline sociological & 9.80 & 0.70 & 0.49 & 0.09 & 0.00 & 0.00 & 0.35 & 0.01 \\
\hline stress & 33.56 & 1.48 & -1.15 & -0.23 & 0.00 & 0.00 & 0.90 & 0.04 \\
\hline survey & 39.55 & 0.03 & 0.00 & -0.06 & 0.00 & 0.00 & 0.00 & 0.11 \\
\hline trajectories & 14.24 & 0.28 & -0.43 & -0.04 & 0.00 & 0.00 & 0.66 & 0.01 \\
\hline transition & 22.42 & 0.03 & -0.02 & 0.11 & 0.00 & 0.00 & 0.01 & 0.43 \\
\hline treatment & 27.91 & 1.79 & -1.23 & -0.27 & 0.00 & 0.00 & 0.85 & 0.04 \\
\hline uncertain & 2.60 & 0.11 & 0.03 & -0.08 & 0.00 & 0.00 & 0.01 & 0.06 \\
\hline vulnerability & 7.28 & 0.84 & -0.88 & -0.21 & 0.00 & 0.00 & 0.92 & 0.05 \\
\hline wages & 7.55 & 0.71 & 0.57 & 0.24 & 0.00 & 0.00 & 0.46 & 0.08 \\
\hline welfare & 14.37 & 0.22 & 0.18 & 0.35 & 0.00 & 0.00 & 0.14 & 0.58 \\
\hline wellbeing & 24.42 & 0.49 & -0.42 & -0.39 & 0.00 & 0.00 & 0.36 & 0.31 \\
\hline work & 86.04 & 0.09 & -0.12 & -0.16 & 0.00 & 0.00 & 0.16 & 0.28 \\
\hline
\end{tabular}

\begin{tabular}{|l|c|c|c|c|c|c|c|c|}
\hline \multicolumn{4}{|l|}{} & \multicolumn{2}{c|}{ COORDINATES } & \multicolumn{2}{c|}{$\begin{array}{c}\text { CONTRIBU- } \\
\text { TIONS }\end{array}$} & \multicolumn{2}{c|}{$\begin{array}{c}\text { SQUARED } \\
\text { COSINES }\end{array}$} \\
\hline \multicolumn{1}{|c|}{ IDENTIFIER } & REL.WT. & DISTO & $\mathbf{1}$ & $\mathbf{2}$ & $\mathbf{1}$ & $\mathbf{2}$ & $\mathbf{1}$ & $\mathbf{2}$ \\
\hline $\begin{array}{l}\text { adolescent } \\
\text { health }\end{array}$ & 7.00 & 0.72 & -0.12 & 0.56 & 0.00 & 0.00 & 0.02 & 0.44 \\
\hline bipolar disorder & 3.47 & 4.47 & -1.93 & -0.16 & 0.00 & 0.00 & 0.83 & 0.01 \\
\hline breast cancer & 2.62 & 1.83 & -1.15 & -0.34 & 0.00 & 0.00 & 0.72 & 0.06 \\
\hline depressive & 19.90 & 1.07 & -0.97 & -0.26 & 0.00 & 0.00 & 0.88 & 0.06 \\
\hline
\end{tabular}




\begin{tabular}{|l|c|c|c|c|c|c|c|c|}
\hline symptoms & & & & & & & & \\
\hline $\begin{array}{l}\text { educational } \\
\text { attainment }\end{array}$ & 5.10 & 0.04 & -0.02 & 0.05 & 0.00 & 0.00 & 0.01 & 0.05 \\
\hline family structure & 3.88 & 0.14 & 0.26 & 0.19 & 0.00 & 0.00 & 0.51 & 0.27 \\
\hline human capital & 3.25 & 0.25 & 0.31 & 0.21 & 0.00 & 0.00 & 0.39 & 0.17 \\
\hline income dynamics & 3.21 & 0.20 & 0.42 & 0.09 & 0.00 & 0.00 & 0.89 & 0.04 \\
\hline $\begin{array}{l}\text { intergenerational } \\
\text { transm }\end{array}$ & 1.13 & 0.20 & 0.17 & 0.14 & 0.00 & 0.00 & 0.15 & 0.11 \\
\hline labor force & 3.14 & 0.25 & 0.38 & -0.01 & 0.00 & 0.00 & 0.59 & 0.00 \\
\hline labor market & 9.69 & 0.48 & 0.54 & 0.15 & 0.00 & 0.00 & 0.60 & 0.05 \\
\hline life events & 4.83 & 0.99 & -0.94 & -0.28 & 0.00 & 0.00 & 0.90 & 0.08 \\
\hline major depression & 4.79 & 4.14 & -1.88 & -0.13 & 0.00 & 0.00 & 0.85 & 0.00 \\
\hline negative affect & 3.60 & 2.68 & -1.50 & -0.40 & 0.00 & 0.00 & 0.84 & 0.06 \\
\hline $\begin{array}{l}\text { personality } \\
\text { disorder }\end{array}$ & 3.12 & 4.36 & -1.93 & -0.07 & 0.00 & 0.00 & 0.85 & 0.00 \\
\hline personality traits & 2.10 & 2.36 & -1.47 & -0.23 & 0.00 & 0.00 & 0.91 & 0.02 \\
\hline $\begin{array}{l}\text { prospective } \\
\text { memory }\end{array}$ & 1.84 & 3.70 & -1.79 & -0.27 & 0.00 & 0.00 & 0.86 & 0.02 \\
\hline single mothers & 1.35 & 0.73 & 0.41 & 0.37 & 0.00 & 0.00 & 0.23 & 0.19 \\
\hline social capital & 5.33 & 0.22 & 0.21 & -0.23 & 0.00 & 0.00 & 0.20 & 0.24 \\
\hline suicide attempts & 2.25 & 1.89 & -1.30 & -0.14 & 0.00 & 0.00 & 0.90 & 0.01 \\
\hline welfare state & 1.69 & 0.45 & 0.48 & -0.02 & 0.00 & 0.00 & 0.51 & 0.00 \\
\hline
\end{tabular}

\section{References}

Armingeon, K., \& Bonoli, G. (2006). The politics of post-industrial welfare states: adapting post-war social policies to new social risks. London: Routledge.

Baltes, P., Lindenberger, U., \& Staudinger, U. (1998). Lifespan theory in developmental psychology. In R. Lerner

(Ed.), Handbook of child psychology : Vol. 1 Theoretical Models of Development (pp. 1029-1143) (5 ${ }^{\text {th }}$ ed.). New York: Wiley.

Beck, U. (1992). Risk society: Towards a new modernity. London: Sage.

Benzecri, J. (1992). Handbook of correspondence analysis. New York: Dekker.

Bourdieu, P. (1977). Outline of a Theory of Practice. Cambridge: University Press. http://dx.doi.org/10.1017/CBO9780511812507

Brady, D. (2006). Structural theory and relative poverty in rich western democracies, 1969-2000. Research in Social Stratification and Mobility, 24(2), 153-175. http://dx.doi.org/10.1016/j.rssm.2005.02.004

Brockmann, H. (2010). Why are middle-aged people so depressed? Evidence from West Germany. Social Indicators Research, 97(1), 23-42. http://dx.doi.org/10.1007/s11205-009-9560-4

Bronfenbrenner, U. (1979). Contexts of child rearing: Problems and prospects. American Psychologist, 34(10), 844-850.

Bronfenbrenner, U. (1989). Ecological systems theory: Annals of Child Development. Cambridge, MA: Harvard University Press. http://dx.doi.org/10.1037/0003-066X.34.10.844

Butz, W. P., \& Torrey, B. B. (2006). Some Frontiers in Social Science. Science, 312(5782), 1898-1900. http://dx.doi.org/10.1126/science.1130121

Coheris (2007). Introduction to SPAD. User Guide - Data management. Data analysis. Data mining (SPAD 7.0). Courbevoie, France: Coheris. 
Drentea, P., Clay, O. J., Roth, D. L., \& Mittelman, M. S. (2006). Predictors of improvement in social support: Fiveyear effects of a structured intervention for caregivers of spouses with Alzheimer's disease. Social Science \& Medicine, 63(4), 957-967. http://dx.doi.org/10.1016/i.socscimed.2006.02.020

Dunbar, N., Van Dulmen, M., Ayers-Lopez, S., Berge, J., Christian, C., Gossman, G., Henney, S., Mendenhall, T., Grotevant, H., \& MsRoy, R. (2006). Processes linked to contact changes in adoptive kinship networks. Family Process, 45(4), 449-464. http://dx.doi.org/10.1111/j.1545-5300.2006.00182.x

Ehrenberg, A. (1995). L'individu incertain (édition de poche Pluriel). Paris. France: Calmann-Lévy.

Elder, G. (1985). Perspectives on the life course. In G. Elder (ed.) Life course dynamics: trajectories and transitions, 1968-1980, (pp. 23-49). Ithaca, New York : Cornell University Press.

Elder, G. Jr. (1994). Time, human agency, and social change: Perspective on the life course. Social Psychology Quarterly, 57(1), 4-15. http://dx.doi.org/10.2307/2786971

Elder, G. \& Shanahan M. (2006). The life course and human development. In W. Damon, \& R. Lerner (Eds.), Handbook of Child Psychology: Theoretical Models of Human Development (pp. 665-715). New York: Wiley and Stone.

Elman, C., \& O'Rand, A. (2002). Perceived job insecurity and entry into work-related education and training among adult workers. Social Science Research, 31(1), 49-76. http://dx.doi.org/10.1006/ssre.2001.0718

Engelman, M., Agree, E. M., Meoni, L., \& Klag, M. (2010). Propositional density and cognitive function in later life: Findings from the precursors study. The Journals of Gerontology Series B: Psychological Sciences and Social Sciences, 65(6), 706-711. http://dx.doi.org/10.1093/geronb/gbq064

Esping-Andersen, G. (1990). The three worlds of welfare capitalism. Cambridge, England: Polity Press.

Esping-Andersen, G. (2009). The Incomplete Revolution: Adapting to Women's New Roles. Cambridge, England: Polity Press.

Esping-Andersen, G. (2002). Why we need a new welfare state. Oxford, England: Oxford University Press. http://dx.doi.org/10.1093/0199256438.001.0001

Esser, I., \& Olsen, K. (2011). Perceived job quality: Autonomy and job security within a multi-level framework. European Sociological Review, 28(4), 443-454. http://dx.doi.org/10.1093/esr/jcr009

Friedman, S., Steinwachs, D., Temkin-Greener, H., \& Mukamel, D. (2006). Informal caregivers and the risk of nursing home admission among individuals enrolled in the program of all-inclusive care for the elderly. The Gerontologist, 46(4), 456-463. http://dx.doi.org/10.1093/geront/46.4.456

Gangl, M. (2002). Changing labour markets and early career outcomes: labour market entry in Europe over the past decade. Work, Employment, and Society, 16(1), 67-90. http://dx.doi.org/10.1177/09500170222119254

George, L. (2003). Life course research: achievements and potential. In J. Mortimer \& M. Shanahan (Eds.), Handbook of the Life Course (pp. 671-680). New York: Kluwer Academic. http://dx.doi.org/10.1007/9780-306-48247-2 31

Greenacre, M. (2010). Correspondence analysis in practice. ( $2^{\text {nd }}$ ed.). United States: Chapman and Hall/CRC, Francis Laylor.

Greenhalgh, L., \& Rosenblatt, Z. (1984). Job insecurity: Toward conceptual clarity. Academy of Management Review, 9(3), 438-448.

Ha, J., Carr, D., Utz, R., \& Nesse, R. (2006). Older adults' perceptions of intergenerational support after widowhood how do men and women differ? Journal of Family Issues, 27(1), 3-30. http://dx.doi.org/10.1177/0192513X05277810

Hanappi, D. (2011). Economic action, fields and uncertainty. Journal of Economic Issues, 45(4), 285-803.

Hank, K. (2005). Childbearing history, later-life health, and mortality in Germany. Population Studies, 64(3), 275291. http://dx.doi.org/10.1080/00324728.2010.506243

Heinz, W., \& Marshall, V. (2005). Social dynamics of the life course: Transitions, institutions, and interrelations. Hawthorme, NY: Aldine De Gruyter.

Hofferth, S., \& Goldscheider, F. (2010). Does Change in Young Men's Employment Influence Fathering? Family Relations, 59(4), 479-493. http://dx.doi.org/10.1111/j.1741-3729.2010.00617.x

Klimstra, T., Luyckx, K., Hale III, W., Goossens, L., \& Meeus, W. (2010). Longitudinal associations between personality profile stability and adjustment in college students: Distinguishing among overall stability, 
distinctive stability, and within-time normativeness. Journal of Personality, 78(4), 1163-1184.

Knight, F. (1921). Risk, Uncertainty and Profit. Boston and New York: Kelley.

Kohli, M. (2007). The institutionalization of the life course: Looking back to look ahead. Research in Human Development, 4(3-4), 253-271. http://dx.doi.org/10.1080/15427600701663122

Korinek, K., Entwisle, B., \& Jampaklay, A. (2005). Through thick and thin: layers of social ties and urban settlement among Thai migrants. American Sociological Review, 70(5), 779-800. http://dx.doi.org/10.1177/000312240507000503

Kort-Butler, L. (2009). Coping styles and sex differences in depressive symptoms and delinquent behavior. Journal of Youth and Adolescence, 38(1), 122-136. http://dx.doi.org/10.1007/s10964-008-9291-x

Lebart, L. (1992). Discrimination through the regularized nearest cluster method. In Y. Dodge \& Whittaker (eds.), Computational Statistics. (pp. 103-118). Heidelberg: Physica Verlag.

Lebart, L., \& Mirkin, B. (1993). Correspondence analysis and classification. In C.M. Cuadras \& C.M. Rao (eds.), Data Science and Application (pp. 341-357). Amsterdam: Elsevier.

Lebart, L., Salem, A., \& Berry, L. (2010). Exploring Textual Data, Vol. 4. Dordrecht, Germany: Kluwer Academic Publishers.

Lyonnette, C., Crompton, R., \& Wall, C. (2007). Gender, occupational class and work-life conflict. London, England: Routledge.

Martucellli, D. (2006). Forgé par l'épreuve. Paris, France: Armand Colin.

Mayer, K. (2009). New directions in life course. Annual Review of Sociology, 35, 413-433. http://dx.doi.org/10.1146/annurev.soc.34.040507.134619

McNamara, T., Pitt-Catsouphes, M., Matz-Costa, C., Brown, M., \& Valcour, M. (2013). Across the continuum of satisfaction with work-family balance: Work hours, flexibility-fit, and work-family culture. Social Science Research, 42(2), 283-298. http://dx.doi.org/10.1016/i.ssresearch.2012.10.002

Morineau, A., \& Alija-Banet, T. (1998). Analyse en composants principales (avec illustrations SPAD). Paris: CISIACERESTA.

Mortimer J. T., \& Shanahan M. J. (2003). Handbook of the Life Course. New York: Kluwer Academic. http://dx.doi.org/10.1007/b100507

Mussino, E., \& Bernardi, L. (2010). Parlando di figli: analisi testuale delle aspettative di fecondita. In S. Bolasco, I. Chiari, \& L. Giuliano (Eds.), Statistical analysis of textual data (pp. 951-963). Rome: Sapienza University of Rome.

O'Rand, A. (2003). The future of the life course. Late modernity and life course risks. In J. Mortimer \& M. Shanahan (Eds.), Handbook of the life course (pp. 693-701). New York: Kluwer Academic Publishers.

O'Rand, A. (2006). Stratification and the life course: life course capital, life course risks, and social inequality. In R. Binstock \& L. George (Eds.), Handbook of aging and the social sciences (pp. 145-62). San Diego: Elsevier. http://dx.doi.org/10.1016/B978-012088388-2/50012-2

Paugam, S. (2000). Le salarié de la précarité. Paris: PUF.

Pearlin, L. (1989). The sociological study of stress. Journal of Health and Social Behavior, 30(3), 241-256. http://dx.doi.org/10.2307/2136956

Pintelon, O., Cantillon, B., Bosch, K., \& Whelan, C. (2013). The social stratification of social risks: The relevance of class for social investment strategies. Journal of European Social Policy 23(52), 52-67. http://dx.doi.org/10.1177/0958928712463156

Ranci, C. (2010). Social vulnerability in Europe. In C. Ranci (Ed.), Social vulnerability in Europe. The new configuration of social risks. (pp. 3-24). New York, US: Palgrave McMillan.

Salamin, X., \& Hanappi, D. (2014). Women and international assignments: A systematic literature review exploring textual data by correspondence analysis. Journal of Global Mobility, 3(3), 343-374. http://dx.doi.org/10.1108/JGM-09-2013-0058

Sarfati, H., \& Bonoli, G. (2002). Labour market versus social protection reform. Parallel or convergent tracks? Aldershot, UK: Asghate.

Scherer, S. (2009). The social consequences of insecure jobs. Social Indicators Research, 93(3), 527-547. http://dx.doi.org/10.1007/s11205-008-9431-4

Settersten, R. (2003). Propositions and controversies in life-course scholarship. In R. Settersten (Ed.), Invitation to 
the life course. Toward new understandings of later life (pp. 15-45). Amityville: Baywood.

Sirven, N. (2007). De la pauvreté à la vulnérabilité: évolutions conceptuelles et méthodologiques. Mondes en Développement, 140(4), 9-24. http://dx.doi.org/10.3917/med.140.0009

Spini, D., Ghisletta, P., Guilley, E., Lalive d'Epinay, C. (2007). Frail Elderly. In Online Encyclopaedia of Gerontology

(2nd Edition), (pp. 572-579) Elsevier. http://dx.doi.org/10.1016/B0-12-370870-2/00074-3

Spini, D., Elcheroth, G., \& Figini, D. (2008). Is there space for time in social spychology publications? A content analysis across five journals. Journal of Community and Applied Social Psychology, 19(3), 16-181.

Spini, D., Hanappi, D., Bernardi, L., Oris, M., Bickel, J. (2013). Vulnerability across the life course: a theoretical framework and research directions. Working Paper LIVES No. 27, University of Lausanne.

Streib, G.. \& Binstock, R. (1990). Ageing and the Social Sciencess: Changes in the Field. In R. Binstock and I. George (Eds.), Handbook of Ageing and the Social Sciences (pp. 1-15). New York: Academic Press.

Vandecasteele, L. (2011). The structuring effect of social stratification determinants and life course events on poverty transitions in Europe. European Sociological Review, 27(2), 246-264. http://dx.doi.org/10.1093/esr/jcq005

Walsh, F. (1996). The concept of family resilience: Crisis and challenge. Family process, 35(3), 261-281. http://dx.doi.org/10.1111/j.1545-5300.1996.00261.x

Western, B., Bloome, D., Sosnaud, B., \& Tach, L. (2012). Economic Insecurity and Social Stratification. Annual Review of Sociology, 38(1), 341-359. http://dx.doi.org/10.1146/annurev-soc-071811-145434

Whelan, C., \& Maitre, B. (2008). New and Old Social Risks: Life Cycle and Social Class Perspectives on Social Exclusion in Ireland. The Economic and Social Review, 39(2), 131-156.

\section{Endnotes}

${ }^{1}$ Note that excluding the medical and epidemiological studies is a thematic choice for assessing vulnerability as an interdisciplinary heuristic in the social sciences. Unlike including the vast amount of medical and epidemiological research, concentrating on sub-disciplines within our primary field of interest-the social sciences-allows us to better distinguish diverse themes covered and methods used in the field of interest.

${ }^{2}$ For each row entry (article), each term from the first column was combined with terms from the second or third column using the "AND" operator. Terms within the same columns were searched by using the "OR" operator. The key search terms were searched in the abstracts of each row entry.

${ }^{3}$ General social science journals include multidisciplinary and applied sciences journal abstracts.

${ }^{4}$ Note that life stages are plotted into the graphical representation as supplementary variables, thus having contributions of zero.

${ }^{5}$ Terms such as 'bipolar disorder' or 'labour market' in bold refer to terms represented in the two-dimensional display generated by correspondence analysis (see Figure 1 ).

${ }^{6}$ The term 'panel data' is primarily used in sociological, demographic, and socio-economic journal publications, while the term 'longitudinal studies' is often used synonymously in psychology and the social sciences. 